Original Articles

\title{
Setting the stage for new ecological indicator species: A holistic case study on the Iberian dolphin freshwater mussel Unio delphinus Spengler, 1793
}

\author{
Manuel Lopes-Lima ${ }^{\mathrm{a}, \mathrm{b}, \mathrm{c}, *}$, Mariana Hinzmann $^{\mathrm{b}}$, Simone Varandas ${ }^{\mathrm{d}}$, Elsa Froufe ${ }^{\mathrm{b}}$, Joaquim Reis ${ }^{\mathrm{e}}$, \\ Cláudia Moreira ${ }^{\mathrm{b}, \mathrm{f}}$, Sandra Araújo $^{\mathrm{b}}$, Fernando Miranda ${ }^{\mathrm{g}}$, Duarte V. Gonçalves ${ }^{\mathrm{a}, \mathrm{b}}$, Pedro Beja ${ }^{\mathrm{a}, \mathrm{h}}$, \\ Ronaldo Sousa ${ }^{\mathrm{i}}$, Amílcar Teixeira ${ }^{\mathrm{g}}$ \\ ${ }^{a}$ CIBIO/InBIO - Research Center in Biodiversity and Genetic Resources, University of Porto, Campus Agrário de Vairão, 4485-661 Vairão, Portugal \\ ${ }^{\mathrm{b}}$ CIIMAR/CIMAR - Interdisciplinary Centre of Marine and Environmental Research, Terminal de Cruzeiros do Porto de Leixões, Av. General Norton de Matos $s / n$, 4450- \\ 208 Matosinhos, Portugal \\ ${ }^{\mathrm{c}}$ IUCN SSC Mollusc Specialist Group, c/o IUCN, David Attenborough Building, Pembroke St., Cambridge, United Kingdom \\ ${ }^{\mathrm{d}}$ CITAB-UTAD - Centre for Research and Technology of Agro-Environment and Biological Sciences, University of Trás-os-Montes and Alto Douro, Forestry Department, \\ Apartado 1013, 5001-811 Vila Real, Portugal \\ ${ }^{\mathrm{e}}$ MARE - Marine and Environmental Sciences Centre Faculdade de Ciências da Universidade de Lisboa Campo Grande, 1749-016 Lisboa, Portugal \\ ${ }_{\mathrm{f}}^{\mathrm{f}}$ Instituto de Ciências Biomédicas Abel Salazar da Universidade do Porto (ICBAS/UP), Rua Jorge Viterbo Ferreira 228, 4050-313 Porto, Portugal \\ ${ }^{\mathrm{g}}$ CIMO-ESA-IPB - Mountain Research Centre, School of Agriculture, Polytechnic Institute of Bragança, Campus de Santa Apolónia, Apartado 1172, 5301-854 Bragança, \\ Portugal \\ ${ }^{\mathrm{h}}$ CIBIO/InBIO - Research Center in Biodiversity and Genetic Resources, Instituto Superior de Agronomia, Universidade de Lisboa, Tapada da Ajuda, $1349-017$ Lisboa, \\ Portugal \\ ${ }^{\mathrm{i}}$ CBMA - Centre of Molecular and Environmental Biology, Department of Biology, University of Minho, Campus Gualtar, 4710-057 Braga, Portugal
}

\section{A R T I C L E I N F O}

\section{Keywords:}

Conservation

Unionida

Life-history traits

Growth

Host-fish

\begin{abstract}
A B S T R A C T
Due to their sensitivity and dramatic declines, freshwater mussels are prime targets for conservation and environmental monitoring. For this, however, information is needed on life history and ecological traits, which is lacking in many taxa, including threatened species. Species recently described or recognized as valid are of particular concern, due to the shortage of even basic knowledge. A case in point is the recently recognized and Near Threatened dolphin freshwater mussel Unio delphinus Spengler, 1793, which is endemic to the western Iberian Peninsula and has suffered marked population declines. To overcome information gaps for U. delphinus, we carried out a holistic biological study across the species range, aiming to: i) estimate the area of occupancy (AOO) and extent of occurrence (EOO) based on updated distribution data taken from the literature and recent surveys; ii) estimate growth patterns from biometrical (shell dimensions and growth annuli) measurements taken on specimens from seven populations; iii) estimate sex ratios from gonad tissue biopsies collected on specimens from eight populations; iv) estimate gametogenesis and sex ratio through histological examination of gonad and gill tissues collected monthly for a year, from a single population; and v) determine host species from infestation trials of glochidia with co-occurring fish species. We estimated an EOO of $706 \mathrm{~km}^{2}$ and an AOO of $61 \mathrm{~km}^{2}$, which together with data on declines assigns the species to the Endangered category using IUCN criteria. Unio delphinus was found to grow faster and to be shorter-lived (up to 11 years, maturity at around 2 years old) than other European freshwater mussels. Growth and life span are similar across the range in lotic habitats, but different from that in lentic habitats. The larvae of $U$. delphinus may attach to most co-occurring fish species, but only native species were effective hosts. Native cyprinids, especially those from the genus Squalius, seem to be the primary hosts. Overall, the information provided contributes to a better conservation status assessment, selection of conservation and rehabilitation areas, guidance for the establishment of propagation programs and better timing for specimens' manipulation including monitoring and possible translocations. The framework presented here highlights the importance of basic biological studies to define good ecological and physiological status.
\end{abstract}

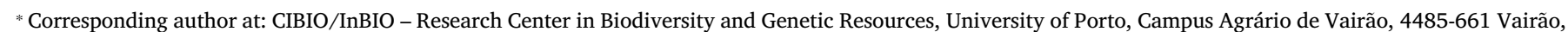
Portugal.

E-mail address: manuelpmlopeslima@gmail.com (M. Lopes-Lima). 


\section{Introduction}

The definition and requirements of ecological indicators have been subject to some debate and confusion, but indicator species are undoubtedly important components for ecosystem quality assessments (Heink and Kowarik, 2010). A highly cited review by Carignan and Villard (2002) identified two ideal general qualities for indicator species: negative association with human disturbance, and habitat specialisation. Additional characteristics were described from previous studies (Noss et al., 1997): the potential as an early warning system, the discrimination of the cause of change, the range of responses, and the cost-effectiveness of the survey. Potential indicator species are often at the same time keystone, area-limited 'umbrella', dispersal-limited, resource-limited, process-limited, or flagship species (Carignan and Villard, 2002; Lambeck, 1997; Noss et al., 1997). However, even when matching all these criteria, there is still a need for several disparate indicators, since each species reacts to disturbances at different degrees and scales (Carignan and Villard, 2002). Finally, for a species to be useful as an ecological indicator, it needs first and foremost to be very well studied, so that survey data allows distinguishing actual disturbance signals from variations that may be unrelated to the deterioration of ecological integrity (Carignan and Villard, 2002).

The bivalves of the Unionida order, also known as freshwater mussels, are key elements of aquatic ecosystems (Lopes-Lima et al., 2014, 2018). They play ecologically important roles such as bioturbation or sediment mixing, nutrient cycling and energy transfer from the water column to the bottom, among other processes (Vaughn, 2018). However, this faunal group, like most others in freshwater ecosystems, has been declining dramatically over the last decades, with several species extinctions and many extirpations being reported (Lopes-Lima et al., 2014, 2018). Freshwater mussels are very sensitive to human activities, but other intrinsic features increase the probability of extirpation or extinction. For instance, these organisms generally have a slow metabolism, taking at least a year to reach sexual maturity (LopesLima et al., 2017a). Also, they have a complex life cycle where larvae (glochidia) need to attach to specific fish hosts (Modesto et al., 2018). Given their important ecological role, but also high sensitivity to habitat, water, and sediment quality, some freshwater mussel species simultaneously fulfil criteria for indicator, flagship, and umbrella species, making them important targets for environmental monitoring and conservation (Geist, 2010; Lopes-Lima et al., 2017a). Like some freshwater mussel species (e.g. Margaritifera margaritifera), umbrella species conservation strategies are directed towards wide home range species providing protection to other sympatric species (Geist, 2010). This is due to the high sensitivity of freshwater mussels to environmental factors that can arise at different spatial scales, not only local but also regional such as the land-use and geological influence over the whole catchment area (Strayer et al., 2004). Freshwater mussels are also highly valued for their rarity, beauty and interesting behaviour (Strayer, 2017), which added to their tight interspecific relationships and frequently high cultural value make them suitable 'flagship species" to raise support for freshwater habitat conservation (Caro, 2010). Due to their unique and crucial roles in ecosystem functioning, and the high biomass in many habitats, they can also be considered ecosystem engineers, given their large physical effects on the ecosystem (Gutierrez et al., 2003).

In Europe, 20 freshwater mussel species are currently recognized (Froufe et al., 2016a, 2016b, 2017; Lopes-Lima et al., 2017a; Araujo et al., 2018). Species richness is higher in central Europe but southern Europe presents a higher level of endemism and restricted-range species (Lopes-Lima et al., 2017a). This is the case of the dolphin freshwater mussel Unio delphinus Spengler, 1793, which was considered a subspecies of the widespread and more common European Unio pictorum until its recent recognition as a valid distinct species (Araujo et al., 2009). Unio delphinus has suffered a $30 \%$ range decline over the last decades, mainly due to habitat degradation, including pollution and changes in the hydrologic regime due to the presence of dams or other infrastructures, poor river management and water shortage (Araujo, 2011). The Iberian Peninsula, as most of the regions within the Mediterranean biodiversity hotspot (Myers et al., 2000), is suffering from water scarcity exacerbated by climate change and associated instability (Robson et al., 2013; Cid et al., 2017). Similar negative impacts were observed on the Iberian populations of other freshwater mussel species (Sousa et al., 2012, 2018).

Invasive species are also pointed as one of the main threats to freshwater mussels (Sousa et al., 2014). Introduced predators like mammals, fish, and crayfish are known to consume freshwater mussels and may cause local declines (Meira et al., 2019; Sousa et al., 2018, 2019). Zebra mussels Dreissena polymorpha and the Asian clam Corbicula fluminea can reach high densities in their invasive ranges and may outcompete native mussels, reducing their fitness and growth and increasing mortality rates (Sousa et al., 2011; Bódis et al., 2014; LopesLima et al., 2017a; Ferreira-Rodríguez et al., 2019; Modesto et al., 2019). Given that native mussels seem to depend on specific, and usually native fish host species to complete their life cycle, changes in the fish fauna can also have deep implications on the mussel populations (Douda et al., 2013; Modesto et al., 2018).

Over the last decades, there has been a rising awareness about the need to conserve freshwater ecosystems and taxa, accompanied by the increase of dedicated conservation funds, mainly in Europe and North America (Lopes-Lima et al., 2017a, 2018). This has also boosted research on freshwater mussel conservation (Lopes-Lima et al., 2014). However, in Europe the majority of studies were concentrated on a small number of species present on the European Union (EU) Habitats Directive, disregarding most of the other freshwater mussels, especially those that were only recognized after the inception of that EU policy (Lopes-Lima et al., 2018), as is the case for U. delphinus. On the other hand, most recent research explores threats, management and conservation methods (Lopes-Lima et al., 2014), but much less effort has been devoted to understand the underlying life-history traits that are essential for effective conservation planning (Lopes-Lima et al., 2014, 2017a). These concerns have been raised in recent reviews that identify as top conservation research priorities acquiring information on lifehistory traits, abundance, distribution, and size structure (Lopes-Lima et al., 2018, Ferreira-Rodríguez et al., 2019).

Given the high sensitivity and filtering behaviour of freshwater mussels, they are many times colloquially mentioned as "aquatic canaries in the coalmine" or "livers of the rivers" (Cummings et al., 2016). Demographic, physiological and behaviour features can be used to determine the status of a freshwater mussel population and therefore indicate potential environmental perturbation (Van Hassel and Farris, 2007). Basic biological features of freshwater mussels have already been used to assess environmental disturbance in freshwater habitats, such as the effects of temperature and heated effluents, sewage, siltation, and impoundment (reviewed in Van Hassel and Farris, 2007 and references therein). Many of the same characteristics that make freshwater mussels good sentinel organisms (e.g., sedentarism, large/easy to use, sensitive to disturbance, shells providing historical record, widely distributed, and bioaccumulation of pollutants) also make them well suited to use as indicators of ecological integrity in assessments of environmental impact, waterbody status monitoring, and assessments of environmental history (Van Hassel and Farris, 2007). However, studies using freshwater mussels as biological indicators are still scarce (LopesLima et al., 2014) due to the limited knowledge about their life-history traits.

To face the dearth of life-history trait research and to set up a framework that can serve both as an example and base for future works, the present work applies a holistic approach to study $U$. delphinus and thus improve the efficacy of ongoing and future conservation measures and their use as environmental indicators. We update the distribution and revise the conservation status of $U$. delphinus focusing on eight $U$. delphinus populations to study the species growth and lifespan patterns 
throughout its range, determine and describe its reproductive cycle and sexuality, and identify its fish hosts.

\section{Materials and methods}

\subsection{Distribution}

Distribution data was compiled from the literature and personal data from the authors. The Extent Of Occurrence (EOO) and Area Of Occupancy (AOO) were estimated by two distinct methods. For estimating AOO, the number of occupied cells in a uniform $2 \times 2 \mathrm{~km}$ grid, covering the entire range of the species taxon, was counted and then obtaining the total area of all occupied cells. This method is the one proposed in the most recent version of the IUCN guidelines (Standards and Petitions Committee, 2019) but, in our opinion, it overestimates the AOO for linear distributed species such as freshwater mussels. Therefore, we used another method to estimate AOO which better represents the known area occupied by the taxon. This method to estimate AOO was first used by Gomes-dos-Santos et al. (2019) and consists in multiplying the mean width of the river by a longitudinal (along the river) $2 \mathrm{~km}$ buffer, for each record point and then tallying up the number of records. The mean river width was obtained per basin as the average of six equidistant points within the species range. As for EOO, the first method used was the least convex polygon, as the smallest polygon in which no internal angle exceeds 180 degrees and which contains all the sites of occurrence, as suggested by the IUCN guidelines (Standards and Petitions Committee, 2019). However, since most of the species EOO is on land we feel that the terrestrial range should not be accounted for, and therefore we used also a second alternative method recently published by Gomes-dos-Santos et al. (2019). This method consisted in multiplying the mean river width by the sum of the river length between species distribution records in each basin.

\subsection{Sampling}

Live specimens ( $\mathrm{n} \geq 30$ per population) of $U$. delphinus with varied sizes were collected from eight populations on Atlantic Iberian river basins (Sabor River: 41.239625, -6.967942; Douro River: 41.152612, -7.765184; Mira Lagoon: 40.441897, - 8.756483; Barrinha Lagoon: 40.450047, -8.797069; Mondego River: 40.204369, -8.361042; Ponsul River: 39.778456, -7.432322; Guadiana River: 38.831016, -7.085385; and Vascão River: 37.516950, -7.579433) (Fig. 1), chosen to represent a wide range of latitudes and habitats. All sites contain well-established and healthy populations of $U$. delphinus and display a good ecological and chemical status (Reis, 2006; Oliveira et al., 2007; SNIRH, 2019) and never suffered from known acute events of pollution.

The shells and growth rings of all specimens were measured (see below Section 2.3 for further details) for seven of these eight populations (excluding the Ponsul River population).

For the seasonal sexual development and determination of the age of maturity, 10 specimens of $U$. delphinus were collected from the Sabor River population each month for one year (Fig. 1). The mussels were transported in a refrigerated box and processed within $24 \mathrm{~h}$. The mussels were anesthetized as described in Hinzmann et al. (2013) and euthanized for histological inspection (see below Section 2.4 for further details). To minimize eventual negative impacts, the number of animals sacrificed was kept to a minimum.

Gonad tissue biopsies were collected for seven of these eight populations, (excluding the River Douro Population). All specimens measured and biopsied (see below Section 2.5 for further details), were then returned to their original locations.

For the host compatibility experiments, 14 native and 6 non-native fish species, representing the most common fish taxa with an overlapping distribution with $U$. delphinus (Oliveira et al., 2007; Lopes-Lima et al., 2017a) were collected by electrofishing. For the same experiment, six gravid mussels were collected from the Douro River population and transported to the laboratory (see below further details about hosts in Section 2.6).

\subsection{Growth and longevity}

Shell dimensions (length, width, and height) and the annuli or growth rings were measured from each individual following Aldridge (1999). Individuals with shell abnormalities, incomplete annuli, and eroded shell umbos were excluded from the analysis.

The length of the annuli dimensions was used to produce length-age plots for each population. Growth curves were constructed using the Von Bertalanffy equation (Bauer, 1992; Aldridge, 1999).

The Equation was used in the form: $L_{t}+m=c L_{t}+d$

Where:

$L_{t}$ is the shell length at time $\mathrm{t}$;

$L_{t+m}$ is the shell length at time $\mathrm{t}+\mathrm{m}$;

$m$ is the measurement collection interval (1 year in the present case, i.e. $\mathrm{m}=1$ );

$c=\mathrm{e}^{-\mathrm{km}}$ being $\mathrm{k}$ the growth constant defining the rate at which the asymptotic length is reached;

$\mathrm{d}=\mathrm{L} \infty(1-\mathrm{c})$, being $\mathrm{L} \infty$ the asymptotic length.

The equation coefficients have been previously calculated with the construction of Walford plots (Walford, 1946) of $\mathrm{L}_{t}+1$ against $\mathrm{L}_{t}$, where $L_{t}$ is the length of the shell at time $t$.

Where:

$c$ is the slope of the line;

$d$ is the y-intercept of the line;

$L \infty$ is the length at which a line intersects a line running $45^{\circ}$ from the origin.

For each population, the longest mussel length was used to calculate the maximum age at each site, using the following formula $t_{m}=-1$ / $\mathrm{k} \cdot \ln \left[1-\left(\mathrm{L}_{\mathrm{m}} / \mathrm{L} \infty\right)\right]$ (Ziuganov et al., 1994).

Analyses of Covariance (ANCOVA) implemented in PAST 3.25 (Hammer et al., 2001) were then used to compare growth models.

\subsection{Reproductive cycle histological procedure}

The gonad and gill tissues were removed from each animal. Sex determination was first made from smears of fresh gonad tissue (across the whole gonad) observed under the microscope, and the macroscopic and microscopic aspects of the gonads were recorded. The gonad tissue samples were then fixed in Bouin's (Panreac) solution for a week, cut and inserted into histologic cassettes, and dehydrated in an ethanol gradient followed by xylene and paraffin impregnation overnight, using a Shandon Citadel 2000 Tissue Processor. To finalize, samples were included in paraffin blocks using a Shandon HistoCentre 2. Sections of 5-6 $\mu \mathrm{m}$ were made on a Leica RM2255 microtome and stained using standard H\&E coloration (following Hinzmann et al., 2013). Observations were made on an Olympus DX 41 with DP 70 camera. A division of the main stages of male and female gonadal development or Gonadal Development Index (GDI) was then established for $U$. delphinus based on the majority of observed cases in the respective period, as described in Hinzmann et al. (2013). For the determination of the embryonic development periods, the gills were also inspected.

\subsection{Sex ratio distribution and age of maturity}

All specimens were carefully opened with crossed pliers and four small tissue biopsies were collected with a biopsy needle across the foot to an Eppendorf tube, fixed and visualized under the microscope as explained above for the gonad sections. Sex was confirmed by the 


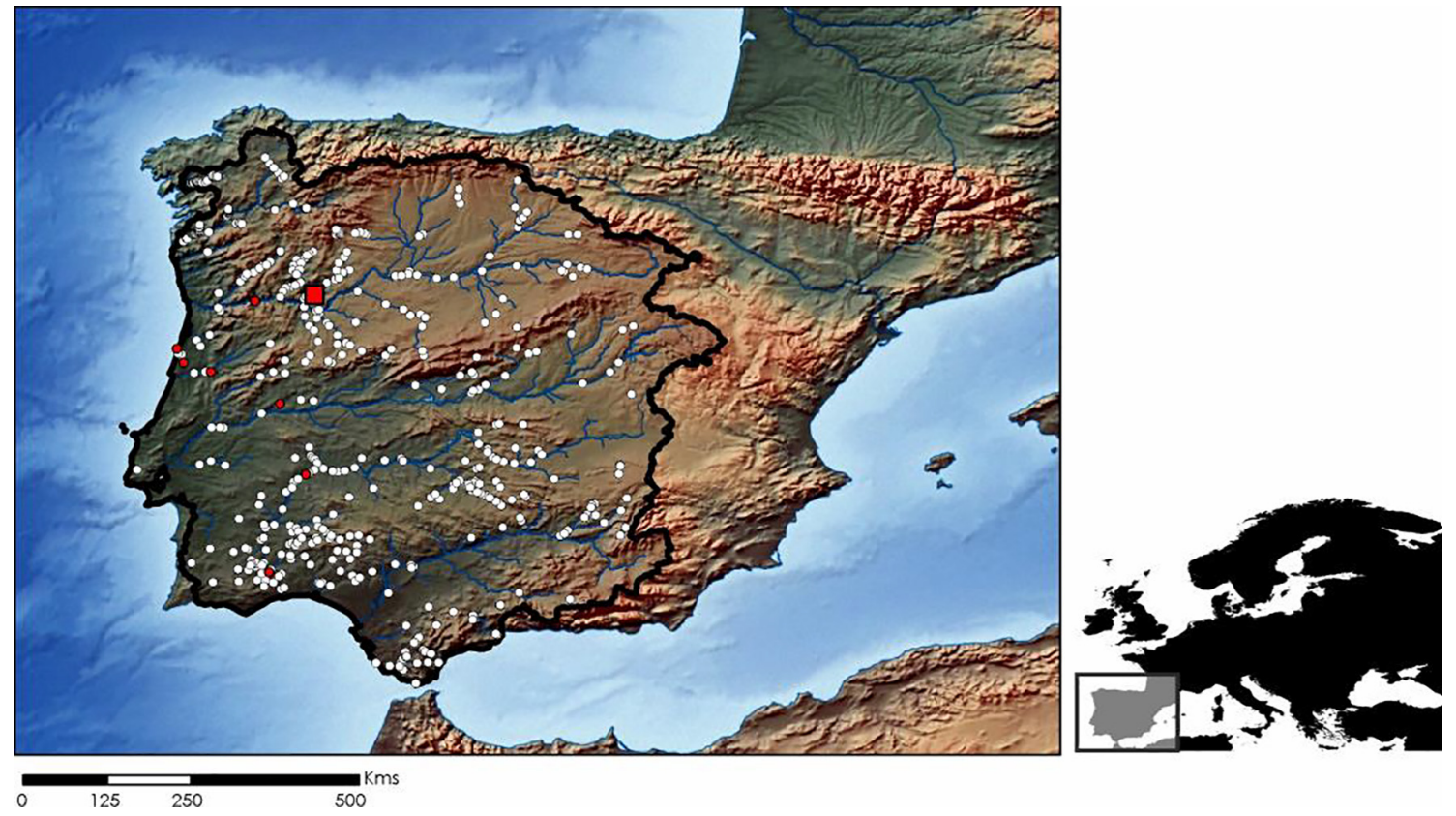

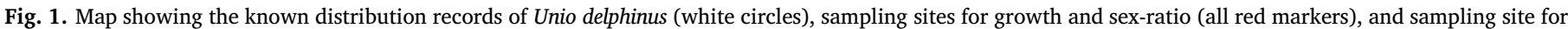
the evaluation of reproductive cycle (red square). Both maps are represented using the World Geodetic System 84 (WGS84) projection.

presence of male or female cells. The approximate age of maturity was determined using the inverse of Von Bertalanffy equation on the age of the younger individuals carrying gamete cells. To assess if sex ratios differed from the 1:1 expectation, a chi-square test was used for each of the seven populations analysed.

\subsection{Fish hosts}

Experiments assessing the infestation capability of $U$. delphinus glochidia with native and non-native fish species were conducted in July 2018. Extraction of the glochidia and infestation trials followed the methodology described in Douda et al. (2013) with a minimal bath volume of $0.5 \mathrm{~L}$ per fish individual containing a mean $\pm \mathrm{SD}$ of $1489 \pm 150$ viable glochidia, added to each tank. All fish were then separated by species in $40 \mathrm{~L}$ tanks (up to 3 fish per tank) to monitor the developmental success of $U$. delphinus glochidia. A 3-mm net was used on the bottom of each tank to avoid juvenile predation by fish. The tanks were part of a recirculation system kept at $20{ }^{\circ} \mathrm{C}$. Fish were fed daily with commercial fish food. Each tank was siphoned daily into filters (mesh size $100 \mu \mathrm{m}$ ), that were examined for the presence of glochidia and juvenile mussels. The proportion of successfully transformed juveniles (transformation rate) was calculated following Douda et al. (2013), using the recorded number of juveniles and the initial number of attached glochidia (determined by the number of dead glochidia + viable juveniles counted from each tank post infestation). The cumulative number of degree-days was calculated by the sum of daily temperatures (all at $20{ }^{\circ} \mathrm{C}$ by controlled temperature) during glochidia attachment. This was determined by multiplying the daily temperature by the number of days during fish infestation. Five days after the last juvenile was recovered, we considered each trial $(N=56)$ to be complete. Fish were then checked for residual attached glochidia.

\section{Results}

\subsection{Distribution}

Unio delphinus populations were recorded in most Atlantic basins of the Iberian Peninsula, from the Ulla River in the north to the La Vega River basin in the south, near Gibraltar. It also occurs in few
Mediterranean coastal basins east of Gibraltar until the Guadalhorce River basin near Malaga (Fig. 1; Appendix 1). The estimated EOO varies between 706 (multiplying the mean river width by the river length within the extremes of the species distribution in each basin) and 344,641 (using the minimum convex polygon EOO estimates) $\mathrm{km}^{2}$. The AOO varies between 61 and $2000 \mathrm{~km}^{2}$ using the mean width of the river along the hydrographic network or $2 \times 2 \mathrm{~km}$ grid overlay methods, respectively.

\subsection{Growth and longevity}

Individuals of all populations grew approximately to $20 \mathrm{~mm}$ in the first year. Then the annual growth rate decreased steadily (Fig. 2). The maximum length measured revealed a major difference between lentic and lotic populations, varying in river populations between about $60-80 \mathrm{~mm}$, while reaching over $100 \mathrm{~mm}$ in both lagoon populations. The von Bertalanffy growth parameters for all populations are represented in Table 1. The growth constant $(\mathrm{k})$ is similar in populations from related habitats, but are much higher for river than lagoon populations (Fig. 2; Table 1), indicating that the asymptotic length is reached sooner in the former. As for the maximum age, populations from the larger rivers, i.e., Douro and Guadiana, attained the longest longevities ( $\approx 11$ years) followed by the lagoon populations ( $\approx 9$ years) and finally by populations colonizing smaller rivers $(\approx 7-8$ years $)$ (Table 1). ANCOVA show significant differences in growth among all populations $(\mathrm{F}=9.4, \mathrm{p}<0.01)$. No significant differences in growth were detected when considering separately lagoon (ANCOVA, $\mathrm{F}=0.07, \mathrm{p}>0.1$ ) and river (ANCOVA, $\mathrm{F}=1.71, \mathrm{p}>0.1$ ) populations.

\subsection{Reproductive cycle}

\subsubsection{General structure of the gonads of Unio delphinus}

The gonads of $U$. delphinus fill most of the foot tissue surrounding the digestive tract. This species is strictly dioecious, as no case of hermaphroditism was detected. Macroscopically, gonad tissue presents sex-specific appearance and coloration. The gonad tissues of females are dark-yellow/orange and are denser and granular, due to the presence of mature oocytes (Fig. 3). The male gonad tissues have a lighter yellow 


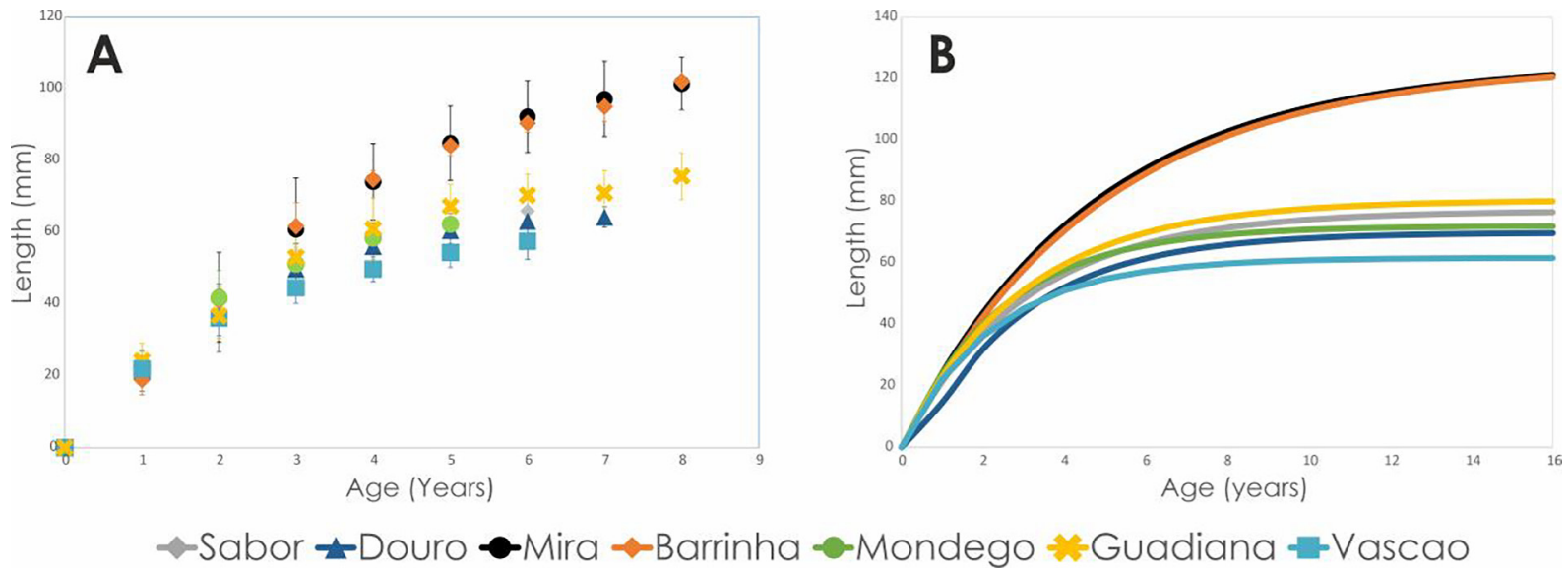

Fig. 2. A - Size-at-age measurements of shell length; B - size as a function of bivalve age, modelled by the von Bertalanffy growth function.

coloration and were more fluid in terms of consistency (Fig. 4). The microscopic organization of the gonads consists of highly branched cell clusters (acini) surrounded by connective and muscular tissue. These acini were found full of gametes throughout the year, independent of sex.

\subsubsection{Oogenesis}

Female individuals presented follicles with reproductive cells in all development stages throughout the year and the reproductive cycle is biannual, continuous and uninterrupted. However, the prevalence of the different stages of development varies seasonally (see GDI subsection below). The oogenesis was mainly divided into five continuous stages, according to the maturation stage of the gamete cell: oogonia, previtellogenic oocytes, early oocytes, oocytes and mature oocytes (Fig. 3).

Oogonia represent the first stage of the gamete development (Fig. 3B), corresponding to the smallest and rounder cells, located radially along the follicle next to the epithelial cells, with a diameter between 10 and $13 \mu \mathrm{m}$. The nucleus is not visible due to the disperse chromatin and the intense pink coloration is due to the cytoplasm acidophilic properties. This stage was rare or inexistent during the peak of maturation and release of mature oocytes (corresponding to stage 4 of the GDI, described below). In the next stage, previtellogenic oocyte (Fig. 3A and C), the size of the cells increased and the nucleus can sometimes be differentiated. Previtellogenic oocytes still present a very acidophilic cytoplasm, and the size of the cells varied between 13 and $18 \mu \mathrm{m}$. These cells can be found in the periphery or slightly internal position in the follicle. The vitellogenic oocytes or early oocytes are bigger ( $20-30 \mu \mathrm{m}$ cell diameter) than the previous stage, but the main difference is the presence of one or more (usually two) nucleolus in the nucleus and their localization that is more internal into the lumen of the follicle. However, early oocytes can still be linked to the germinal epithelium by a peduncle or stalk, as pedunculated oocytes (Fig. 3B and
D). In the following stage, the oocytes, the shape of the cells become more irregular (Fig. 3A, D, E and F), at this stage the cell length can vary between 50 and $60 \mu \mathrm{m}$, the nucleus and the nucleoli are visible in a central position, in some sections is possible to see many vesicles of reserve substances inside the cytoplasm. Finally, the mature oocytes or eggs can reach up to $100 \mu \mathrm{m}$ length (cell diameter usually between 70 and $90 \mu \mathrm{m}$ : Fig. 3A, D, E and F). The aspect of these cells is more diffuse, presenting an acidophilic cytoplasm. The nucleus of mature oocytes is more difficult to observe in section, but when visible it is smaller and with more basophilic characteristics than the cytoplasm (Fig. 3G). At this stage, the gametes are concentrated in the lumen and fill the follicle (Fig. 3D, F and G), giving little space for the other cell stages. It was also possible to observe some mature oocytes already in the ciliated gonoduct (not shown). After the major release events, it is possible to observe a few mature oocytes in the lumen; however, the acini show degenerative signs, being the integrity of the epithelium compromised (Fig. 3H).

\subsubsection{Spermatogenesis}

The process of maturation of the gamete cells is here described in four stages, although they occur simultaneously: spermatogonia, spermatocytes, spermatids, and spermatozoa, which corresponds to the mobile mature phase of the gametes (Fig. 4). The maturation of the cells in the male follicle is concentric, with the early stages located more in the periphery and the mature spermatozoa filling the centre of the lumen (Fig. 4A and E). Each cell stage shows a tendency to aggregate in clusters, especially the spermatocytes and the spermatids (Fig. 4C). In the case of spermatids, they were frequently found under the shape of morulae, where groups of 3-12 cells could be found together (Fig. 4C, D and E). Spermatogonia are the first stage of maturation of the male gametes (Fig. 4C and D). It corresponds to the larger cells with a diameter between 6 and $9 \mu \mathrm{m}$ and a more irregular shape. They were less frequently found in the sections. These cells were usually found in the

Table 1

Growth parameters for Iberian Unio delphinus populations. $\mathrm{L} \infty$ is calculated from the Wolford equation, $\mathrm{L}_{\max }$ is the maximum observed length in the field. Maximum age was estimated from $L_{\max }$.

\begin{tabular}{|c|c|c|c|c|c|}
\hline Population & Wolford plot & Growth constant $(\mathrm{k})$ & Asymptotic length $\mathrm{L}^{\infty}(\mathrm{mm})$ & Maximum length $\mathrm{L}_{\max }(\mathrm{mm})$ & Maximum age (years) \\
\hline \multicolumn{6}{|l|}{ LENTIC } \\
\hline Mira Lagoon & $\mathrm{y}=0.81 \mathrm{x}+23.98\left(\mathrm{R}^{2}=0.996\right)$ & 0.22 & 125.04 & 106.95 & 9 \\
\hline $\begin{array}{l}\text { Barrinha Lagoon } \\
\text { LOTIC }\end{array}$ & $y=0.81 x+23.51\left(R^{2}=0.991\right)$ & 0.21 & 125.04 & 104.94 & 9 \\
\hline Sabor River & $y=0.72 x+21.68\left(R^{2}=0.996\right)$ & 0.33 & 76.88 & 69.08 & 7 \\
\hline Douro River & $y=0.68 x+22.18\left(R^{2}=0.993\right)$ & 0.38 & 69.85 & 68.8 & 11 \\
\hline Mondego River & $\mathrm{y}=0.67 \mathrm{x}+24.10\left(\mathrm{R}^{2}=0.991\right)$ & 0.41 & 71.95 & 68.66 & 8 \\
\hline Guadiana River & $\mathrm{y}=0.71 \mathrm{x}+23.39\left(\mathrm{R}^{2}=0.984\right)$ & 0.34 & 80.34 & 78.19 & 11 \\
\hline Vascão River & $y=0.65 x+21.69\left(R^{2}=0.998\right)$ & 0.44 & 61.63 & 58.98 & 7 \\
\hline
\end{tabular}




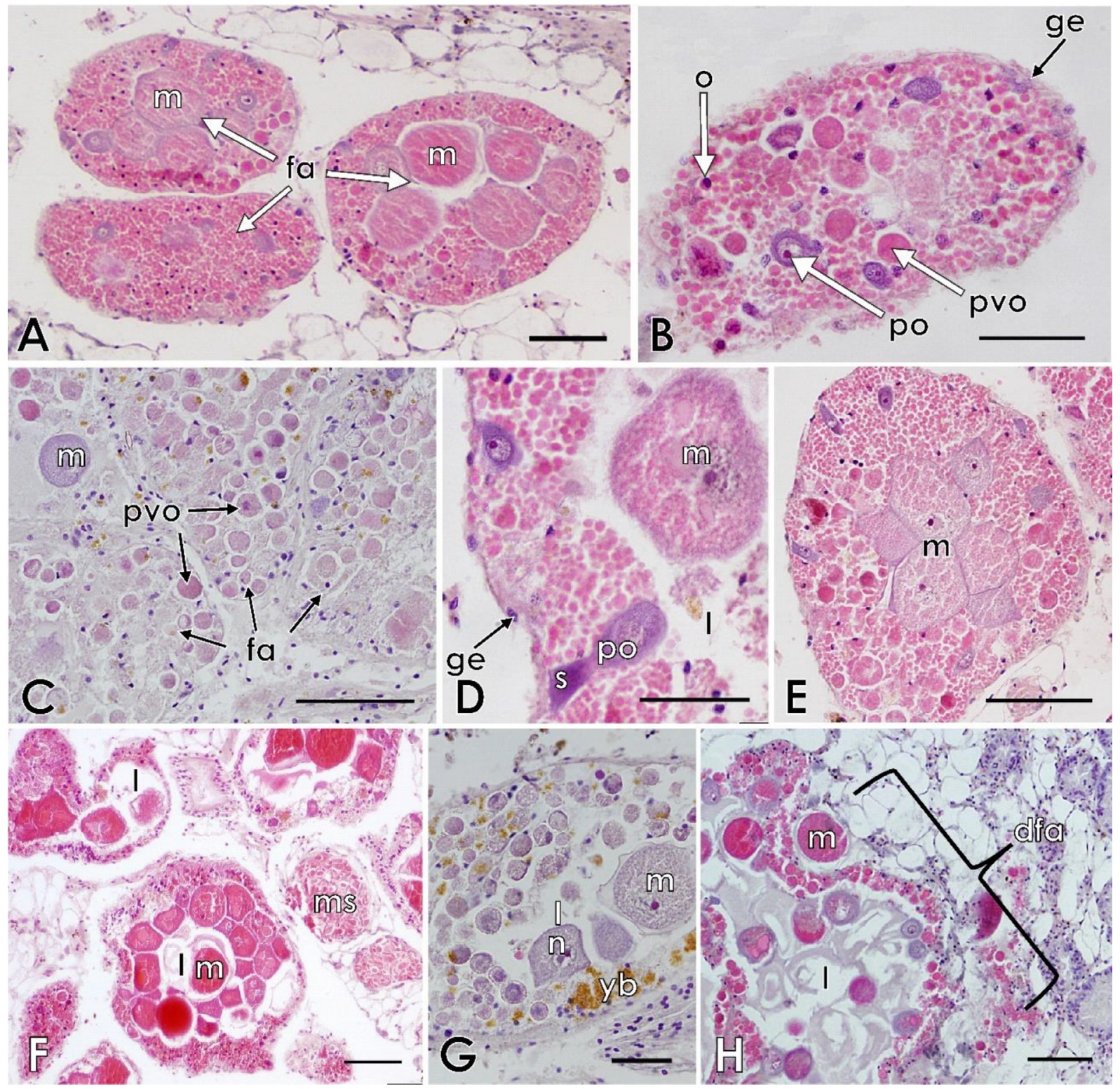

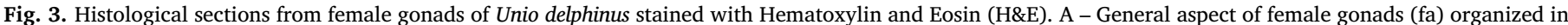

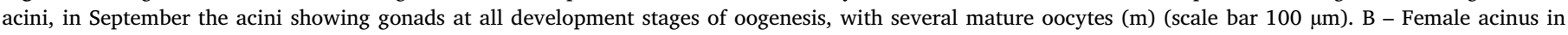

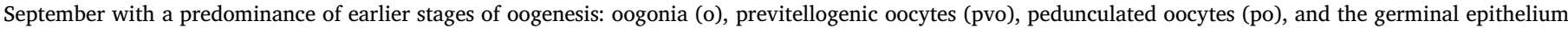

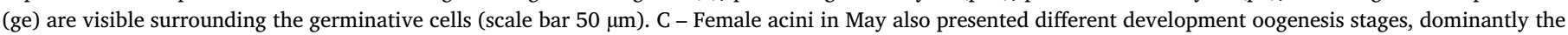

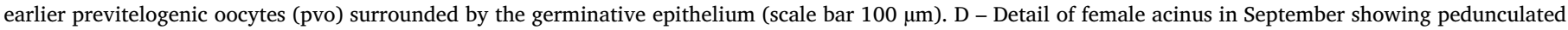

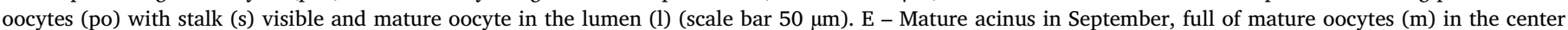

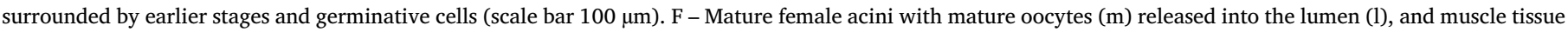

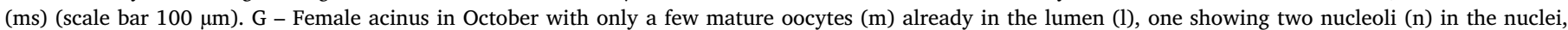

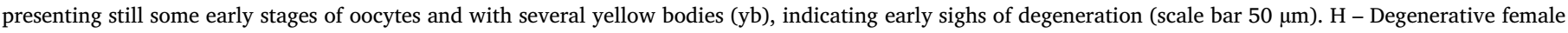
acinus (dfa), surrounded by an undifferentiated epithelium, but still presenting some stages of oocyte development (scale bar $100 \mu \mathrm{m}$ ).

periphery of the follicle, with lighter basophilic coloration. The interior of the spermatogonia is filled by the nucleus, with condensed chromatin. The spermatogonia then pass to a second stage, the spermatocyte, through mitotic division (Fig. 4C and D). With a spherical shape, smaller size, and a diameter between 4 and $6 \mu \mathrm{m}$, spermatocytes present dense chromatin that almost fills the whole cell, being the nuclear membrane hardly visible. These cells develop by meiosis into spermatids which are even smaller and rounder cells (3-4 $\mu \mathrm{m}$ diameter) (Fig. 4C and D). Spermatids are darkly marked with the dye, highly basophilic, and present a polyhedral shape and homogenous dark nucleus. These cells usually have a more internal distribution than the previous ones, and they are frequently organized in morulae, where clusters of 3 to more than 12 spermatids can be found. The spermatids develop then into the final stage of maturation, i.e. the spermatozoa (Fig. 4A, B, E and F). Spermatozoa were present throughout the year (except in two organisms from August), but with the prevalence of the different development stages, varying seasonally (see GDI section below). In fresh samples the flagella were visible and its activity registered. These cells present a rod shape in which the body length was approximately $3-5 \mu \mathrm{m}$ and the flagella $10-20 \mu \mathrm{m}$. The spermatozoa with an oval shape had a very basophilic coloration, the cell diameter varies between 2.0 and $2.5 \mu \mathrm{m}$. In many sections, it was possible to observe the concentration of spermatozoa in the male ciliated gonoduct, ready for spawning (Fig. 4B). Associated with the reproductive 

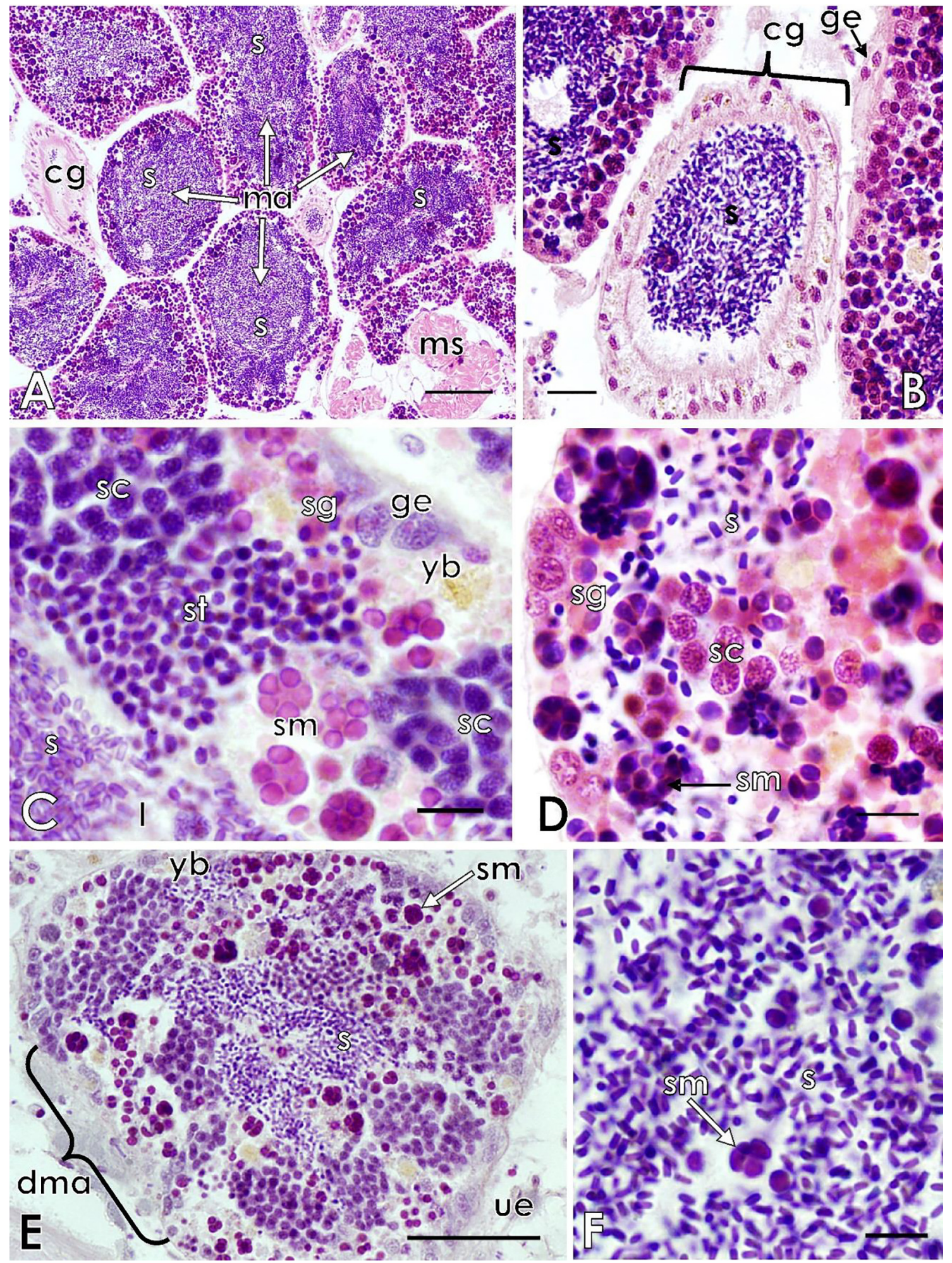

Fig. 4. Histological sections from male gonads of Unio delphinus stained with Hematoxylin and Eosin (H\&E). A - General aspect of male gonads (ma) organized in acini in January, with the acini showing gonads at all development stages of spermatogenesis, full with mature spermatozoa (s) in the lumen, with visible muscle tissue (ms) and portions of the ciliated gonoduct (cg) (scale bar $200 \mu \mathrm{m})$. B - Partial male acini in January, with male reproductive cells at different spermatogenesis stages and germinative epithelium (ge) visible, in the center the ciliated gonoduct (cg) is full of mature spermatozoa (s) (scale bar $20 \mu \mathrm{m}$ ). C and D - Details of male acinus in October, where is possible to identify different development spermatogenesis stages, dominantly the earlier spermatogonia (sg), spermatocytes (sc), spermatids (st), sperm morulae (sm) and the last stage spermatozoa (s), not so abundant (scale bar $10 \mu \mathrm{m}$ ). E - Degenerative male acinus (dma) in August, at the beginning of the post-spawning period, lumen with already some free spaces, presenting some yellow bodies (yb) and surrounded by an undifferentiated epithelium, still presenting all stages of spermatozoa development (scale bar $100 \mu \mathrm{m}$ ). F - Mature spermatozoa (s) in March, few sperm morulae (sm) and other development stages (scale bar $10 \mu \mathrm{m}$ ). 
Table 2

Monthly values of all identified Gonadal Development Index (GDI) stages in the male and female gonads, and presence/absence of eggs and larvae (glochidia) in the marsupium of Unio delphinus. See text for details on GDI.

\begin{tabular}{llll}
\hline Month & Female gonad $(Q)$ stages & Male gonad $\left(\sigma^{\prime}\right)$ stages & Gills $(Q)$ \\
\hline January & 2,3 & 4,5 & empty \\
February & 2,3 & 4,5 & empty \\
March & 3,4 & $3,4,5$ & empty \\
April & 3,4 & $3,4,5$ & eggs (rare) \\
May & $3,4,5$ & $3,4,5$ & eggs, glochidia \\
June & $4,5,1,2$ & $2,3,4$ & eggs, glochidia \\
July & $4,5,1,2$ & $2,3,4$ & eggs, glochidia \\
August & $5,1,2$ & 4,5 & glochidia \\
September & $5,1,2$ & 1,2 & eggs (residual) \\
October & $1,2,3$ & $1,2,3$ & eggs (residual) \\
November & 4,5 & $3,4,5$ & empty \\
December & 4,5 & $3,4,5$ & empty \\
\hline
\end{tabular}

cells it was always possible to observe the presence of several yellowbrownish bodies or granules in the follicles (Fig. 4C, D and E).

\subsubsection{Gonadal Development Index}

The Gonadal Development Index (GDI) along the year is summarized in Table 2.

3.3.4.1. Female. Following the reproductive cycle, it was possible to differentiate five different stages. Often the same organism presented follicles in different stages, making difficult the representation of cell maturation through time, which varied among individuals and seasons (Table 2).

Stage 1 (early active) and Stage 2 (late active) correspond in average terms to the initial stages of gametes development, occurring in very short periods and almost simultaneously, just after the last stage of development, i.e. stage 5 (resorption) (Table 2).

Stage 3 (mature) corresponds to the phase when gametes reach the maximum maturation. It occurred in two distinct periods, from January to May and in October (Table 2). This stage is also when follicles reach their maximum capacity, being full of mature oocytes, awaiting spawning.

Stage 4 (spawned) is reached when many of the mature oocytes were already released (but some can still be found inside the follicles or the gonoduct). Two peaks of maturation were registered during this stage, one larger from March to July and a shorter one from November to December (Table 2).

Stage 5 (resorption) closely follows the previous stage, and it is characterized by the presence of empty, destroyed or degenerating follicles with some yellow bodies present (Table 2). In this last stage, the presence of some follicles already with gametes in the early stages and some free mature oocytes may also occur. This stage was dominant in August but occurred from May to September and also from November to December. We only identified some organisms being exclusively in this stage during September and October (Table 2). Although the gametogenic activity never ceases completely, there is a decrease in activity during these months (Table 2).

3.3.4.2. Male. Due to the extreme variation among contemporaneously sampled individuals and even across follicles of the same individual, the distinction of the several spermatogenesis stages was more difficult than for oogenesis. Similarly, as females, all male individuals present mature follicles with gametes in a continuous cycle.

Stage 1 (early active). Given that we never observed a complete cessation of the reproductive cycle, follicles containing only early stages of male gametes (spermatogonia and spermatocytes) were never found isolated in this stage. Follicles from this stage were rarely found in organisms that presented also follicles at stage 5 or in others that were already in stage 2 or 3 (April to May and September to October).
Stage 2 (late active) corresponds to the period were all stages of maturation of the male gametes are present, except the mature spermatozoa that can be absent or rare. This stage was only detected in September and October.

Stage 3 (mature) is characterized by the presence of all maturation stages in the male follicles, the follicles are full of mature spermatozoa that completely fill the lumen. This stage occurred from March to May and from October to November, preceding spawning. It is characterized by an abundant presence of mature spermatozoa, but also by the high quantity of all the other stages (more in the periphery) and some yellow bodies. During this period some free spermatozoa may already be observed in the gonoduct.

Stage 4 (spawned) occurred practically throughout the year from January to August (with peaks in March, May, and June) and from November to December. This stage is characterized by a decreasing presence of spermatozoa in the follicles and an increase of the other cell development stages, mainly spermatocytes and spermatids organized in morulae. During this phase, the gonoduct is full of spermatozoa and the follicles presented empty spaces inside, but no degenerative follicles were observed.

Stage 5 (resorption) is almost inexistent, due to the continuity of the cycle, occurring only in few organisms in January, March, August, November, and December. This stage is characterized by the presence of empty follicles or in degeneration in the male reproductive tissue, by fewer reproductive cells and by the abundant presence of yellow bodies. There is a decrease in the number of follicles in the tissue, with some follicles already presenting the early maturation stages of male gametes.

\subsection{Demibranchs}

Unio delphinus females only use the outer pair of the female gills as a brooding chamber, or marsupium, for glochidia (Fig. 5A-5E). The species only kept glochidia in the marsupium during short periods (2-3 weeks) and may, therefore, be classified as tachytictic (short term brooders). When the gills are filled only with eggs, they began to swell and their coloration is intense yellow (Fig. 5D). The brooding gills then become lighter and whitish as eggs mature into glochidia (Fig. 5B and 5E). Eggs were detected from April to July, with two peaks, one in April and one in June. Glochidia were detected from May to August, with two discharge peaks (May and August). The organization of the eggs in the marsupial gill is in small conglutinates with a feather shape (Fig. 5D). These conglutinates are generally composed of a variable content of eggs and/or glochidia that may change throughout the cycle. When glochidia become dominant before discharge, conglutinates become more diffuse and less evident.

\subsection{Sex ratio distribution and age of maturity}

No significant differences were detected from the predicted 1:1 sex ratio in all populations (Table 3). No gametes were detected in individuals smaller than $41 \mathrm{~mm}$ (females) and $31 \mathrm{~mm}$ (males), corresponding to 2.5 years in females and 1.6 years for males, respectively. All individuals with size and age above these thresholds presented either female or male gametes in any stage of maturation.

\subsection{Hosts}

The infestation trials showed that $U$. delphinus glochidia attach mainly to native cyprinids and the native brown trout Salmo trutta fario (Table 4; Fig. 6A). Conversely, glochidia were not as successful in attaching to non-native species, which showed in general much lower infestation rates (Table 4; Fig. 6A).

Unio delphinus glochidia successfully developed in 11 out of 14 native species tested (79\%) (Table 4; Fig. 6B). In contrast, non-native fish species never produced any viable juvenile (Table 4; Fig. 6B). The 


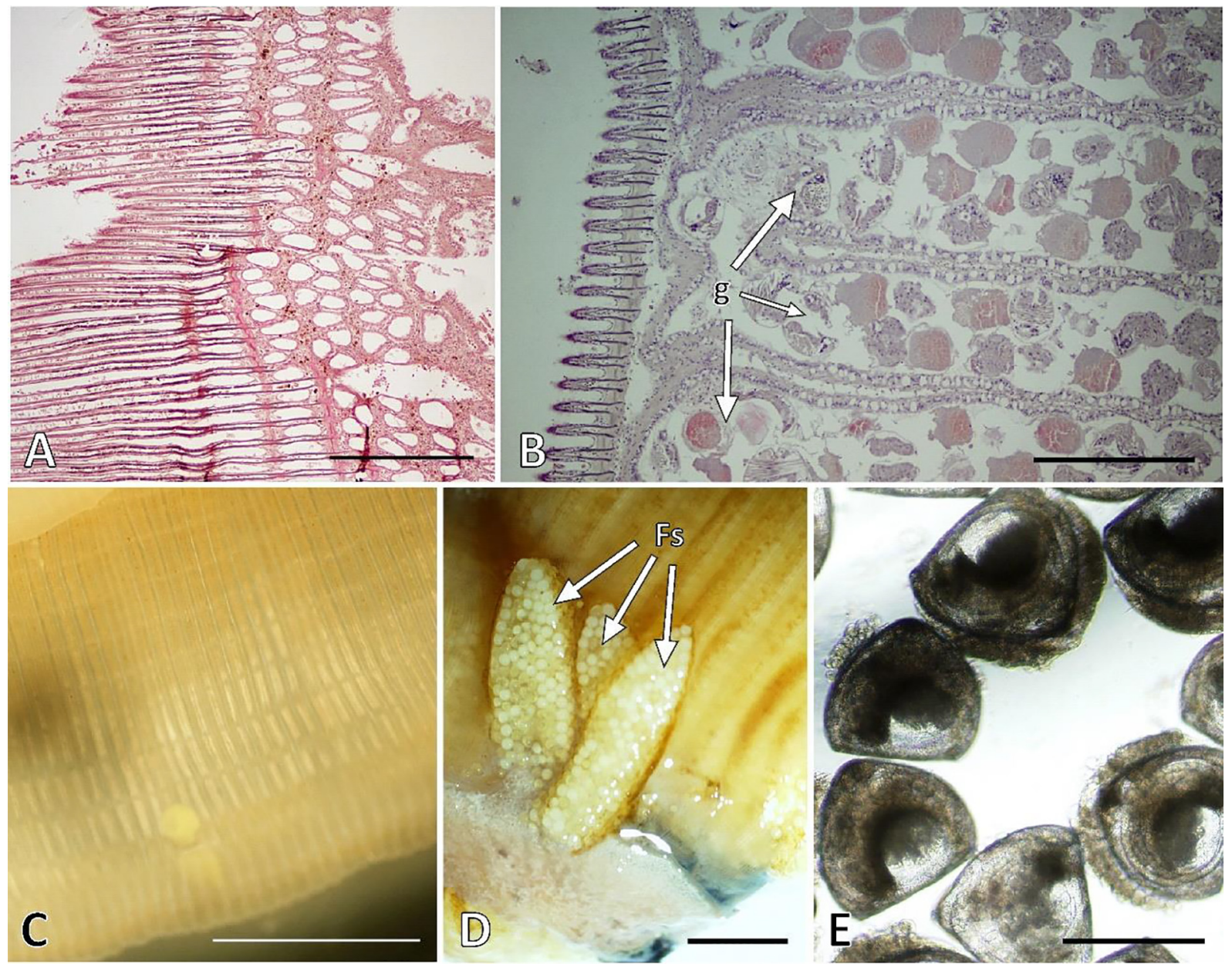

Fig. 5. Histological sections from marsupial female gills of Unio delphinus, without and with glochidia stained with Hematoxylin and Eosin (H\&E) (A and B); stereoscope images from de gills (C and D) and free glochidia (E). A - Histological section from marsupial female gill in April, devoid of offspring (scale bar $500 \mu \mathrm{m}$ ). B - Histological section from marsupial female gills in July, full of mature glochidia (g) (scale bar $500 \mu \mathrm{m}$ ). C - Marsupial gill at stereoscope, in March (scale bar $1 \mathrm{~mm}$ ). D - Detail of gravid gill and feather-like conglutinate full of eggs (Fs) (scale bar $1 \mathrm{~mm}$ ). E - Mature glochidia at the microscope, in June (scale bar $200 \mu \mathrm{m}$ ).

Table 3

Sex distribution of selected Iberian populations of Unio delphinus.

\begin{tabular}{lcc}
\hline Population & \% \% & $\sigma^{\top} \%$ \\
\hline Sabor River & 47.2 & 52.8 \\
Barrinha Lagoon & 44.4 & 55.6 \\
Mira Lagoon & 50.0 & 50.0 \\
Mondego River & 47.4 & 52.6 \\
Tejo River & 48.6 & 51.4 \\
Guadiana River & 40.6 & 59.4 \\
Vascão River & 48.5 & 51.5 \\
\hline
\end{tabular}

glochidia transformation rates ranged from $0 \%$ for the native Southern Iberian spined-loach Cobitis paludica, the European eel Anguilla Anguilla, the flathead grey mullet Mugil cephalus and all non-native species, to $48.8 \%$ for the Northern Iberian chub Squalius carolitertii (Table 4; Fig. 7). Fully developed juveniles were collected from the tanks between 10 and 22 days post infestation, with the sum of daily temperatures during metamorphosis ranging from 240 to 440 degree-days (Table 4; Fig. 7).

\section{Discussion}

This study describes for the first time the main life-history traits of the Iberian dolphin freshwater mussel $U$. delphinus. This information is vital to increase the basic knowledge about the biology and ecology of this species, and it may be used for mainstreaming this species as a valuable environmental indicator and to develop conservation management programs for its populations.

\subsection{Distribution}

Unio delphinus is widely distributed in the Atlantic coast of the Iberian Peninsula, mainly in its larger river basins, i.e., Minho, Douro, Tejo, Guadiana, and Guadalquivir (Fig. 1). This distribution is extended to some smaller river basins north of the Minho and east of the Guadalquivir. Populations south of the Tejo River basin are highly threatened due to habitat degradation and fragmentation, and water shortage. As previously described (Gomes-dos-Santos et al., 2019), estimates of EOO and AOO are largely dependent on the method used. The larger estimates of AOO using the $2 \times 2 \mathrm{~km}$ grid would allow the species to be listed as Vulnerable using the $\mathrm{B}$ criterion but we follow the suggested method of Gomes-dos-Santos et al. (2019), using the mean length of the river as the best estimation method, that places the species as Endangered (Appendix 2).

\subsection{Growth and longevity}

The well-studied freshwater pearl mussel Margaritifera margaritifera and thick-shelled river mussel Unio crassus exhibit slow growth and may live up to 280 and 90 years, respectively (Lopes-Lima et al., 2017a). The present study shows that the Iberian dolphin freshwater mussel $U$. 
Table 4

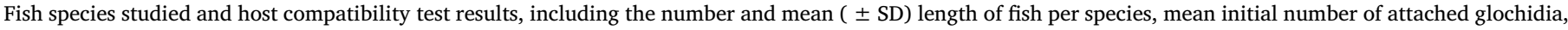

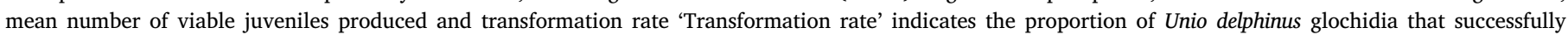
developed into juvenile mussels.

\begin{tabular}{|c|c|c|c|c|c|c|}
\hline Fish Family & Fish Species & Fish $(\mathrm{N})$ & Mean \pm SD fish length $(\mathrm{mm})$ & Mean (glochidia/fish) & Mean (juveniles/fish) & Transformation rate $(\%)$ \\
\hline \multicolumn{7}{|l|}{ NATIVE } \\
\hline ANGUILLIDAE & Anguilla anguilla & 5 & $202.0 \pm 47.6$ & 5.0 & 0.0 & - \\
\hline COBITIDAE & Cobitis paludica & 6 & $80.8 \pm 5.8$ & 16.7 & 0.0 & - \\
\hline \multirow[t]{10}{*}{ CYPRINIDAE } & Achondrostoma oligolepis & 14 & $68.6 \pm 9.1$ & 24.2 & 1.5 & 5.8 \\
\hline & Luciobarbus bocagei & 8 & $134.4 \pm 23.1$ & 160.8 & 111.7 & 41.0 \\
\hline & Luciobarbus comizo & 16 & $90.2 \pm 16.1$ & 113.8 & 29.2 & 20.4 \\
\hline & Luciobarbus microcephalus & 10 & $135.0 \pm 25.1$ & 138.9 & 40.1 & 22.4 \\
\hline & Luciobarbus steindachneri & 12 & $133.3 \pm 20.1$ & 151.5 & 37.2 & 19.7 \\
\hline & Pseudochondrostoma duriense & 7 & $132.0 \pm 5.7$ & 108.8 & 17.2 & 13.7 \\
\hline & Pseudochondrostoma polylepis & 9 & $131.5 \pm 21.1$ & 89.5 & 11.9 & 11.7 \\
\hline & Squalius alburnoides & 11 & $75.9 \pm 7.0$ & 85.1 & 50.9 & 37.4 \\
\hline & Squalius carolitertii & 4 & $85.0 \pm 9.1$ & 197.2 & 188.3 & 48.8 \\
\hline & Squalius pyrenaicus & 6 & $130.0 \pm 7.9$ & 97.5 & 80.9 & 45.3 \\
\hline MUGILIDAE & Mugil cephalus & 3 & $160.0 \pm 8.7$ & 36.3 & 0.0 & - \\
\hline SALMONIDAE & Salmo trutta fario & 5 & $100.0 \pm 15.8$ & 156.7 & 47.0 & 23.1 \\
\hline \multicolumn{7}{|l|}{ NON-NATIVE } \\
\hline \multirow[t]{2}{*}{ CENTRARCHIDAE } & Lepomis gibbosus & 13 & $83.8 \pm 10.2$ & 103.8 & 0.0 & - \\
\hline & Micropterus salmoides & 3 & $123.3 \pm 7.6$ & 37.7 & 0.0 & - \\
\hline CYPRINIDAE & Gobio lozanoi & 6 & $75.8 \pm 10.2$ & 31.3 & 0.0 & - \\
\hline ESOCIDAE & Esox lucius & 3 & $171.6 \pm 12.6$ & 54.7 & 0.0 & - \\
\hline ICTALURIDAE & Ameiurus melas & 3 & $103.5 \pm 6.1$ & 5.2 & 0.0 & - \\
\hline POECILIIDAE & Gambusia holbrooki & 13 & $32.7 \pm 3.9$ & 3.1 & 0.0 & - \\
\hline
\end{tabular}

delphinus presents a distinct growth pattern being a short-lived and fastgrowing unionid species. These results corroborate the trends described within the tribe Unionini, where growth rates are generally faster and life spans shorter than most other unionid groups (Haag and Rypel, 2011). A North-South latitudinal gradient has been previously reported for freshwater mussels growth, with several species showing slower growth but greater longevity for populations living at higher latitudes (Haag and Rypel, 2011), including the European species M. margaritifera (San Miguel et al., 2004) and U. crassus (Helama et al., 2017). This pattern might be explained by the lower temperatures and shorter growth periods of the northern regions (Dunca and Mutvei, 2001; Schöne et al., 2004). Comparing the obtained values of the growth constant $\mathrm{K}$ of the $U$. delphinus populations with previously published results from other Unio species, a marked inter-specific latitudinal gradient is evident: most populations of Unio pictorum from England and Russia (Aldridge, 1999, Rizhinashvili 2008), and U. crassus from Central Europe (Hochwald, 2001; Helama et al., 2017) showed lower K values than those obtained here for $U$. delphinus and those previously published on the other Iberian Unio species, i.e. Unio tumidiformis (Reis and Araujo, 2016) and the Middle eastern Unio terminalis (Ostrovsky et al., 1993). Possibly due to the low number of sites tested and/or the much lower latitudinal distribution of $U$. delphinus compared with $U$. crassus or M. margaritifera, a north-south pattern was not evident for $U$. delphinus populations within Iberia, where growth and longevity showed no significant differences (Table 1). In contrast, the growth constant $\mathrm{K}$ was lower and maximum length higher in the populations from lentic than those from lotic habitats (Fig. 2; Table 1). Freshwater mussel growth is thought to be influenced by productivity and food availability, substrate type, water flow and exposure to wind and current (Haag and Rypel, 2011 and references therein). The larger maximum size and lower $\mathrm{K}$ values of the Lagoon populations in Iberia should be related with the very high productivity and hydrological stability of these habitats (Varandas et al., 2014), when comparing with the River populations. Despite the distinct growth patterns of Lagoon and River populations, the maximum age does not vary considerably between habitat types, ranging between 7 and 11 years old, average 9; Table 1). These values are within the lower end for the European Unio species range that has been reported from 5 to more than 50 and may even reach 90 years years old for the $U$. crassus northern populations
(Lopes-Lima et al., 2017a and references therein).

The age of maturity determined in the Sabor population is higher for females ( 2.5 years) than for males (1.6 years), with a mean maturity value for the species around 2 years, similar to previously reported values for other Unio species (Lopes-Lima et al., 2017a). Based on the maximum longevity and age of maturity, the mean generation length of $U$. delphinus is about 5-6 years.

\subsection{Reproductive cycle and sexual strategy}

No hermaphroditism was detected, showing that $U$. delphinus is strictly dioecious, with a female-male ratio close to 1 but always with a dominance of males (Table 3). Histological studies on other freshwater mussels show that the sexes are typically separate, though hermaphroditism has been detected in some species (Van der Schalie, 1970; Kat, 2009). Nevertheless, the genus Unio seems to be strictly dioecious since no case of complete hermaphroditism has been previously detected for any species (e.g., Aldridge, 1999; Cek and Sereflişan, 2006; Lopes-Lima et al., 2017a).

The reproductive cycle, characterized by the GDI, is continuous and uninterrupted with both male and female reproductive cells being found throughout the year. This contrasts with the reproductive cycle of the congeneric $U$. terminalis and $U$. tumidiformis that seems to exhibit a long and single reproductive cycle (Cek and Sereflişan, 2006; Reis and Araujo, 2016). Brooding and discharge periods overlap with what is known for most Unio species where brooding is coincident with the glochidia discharge period in the spring-summer months (i.e., generally between April and August; Lopes-Lima et al., 2017a and references therein). No glochidia have been found after August which is coherent with results for other Unio species (Lopes-Lima et al., 2017a). This might indicate that we failed to detect a second glochidia discharge period.

Unio delphinus, as all species within the subfamily Unioninae, is ectobranchous (Lopes-Lima et al., 2017b), meaning that the females only use the outer pair of demibranchs as a brooding chamber for glochidia, also known as marsupium (Fig. 5). Glochidia mature and stay in the marsupium during short periods (2-3 weeks) and thus $U$. delphinus can be classified as tachytictic or short-term brooder. Glochidia are discharged by the exhalant aperture to the water column entangled 

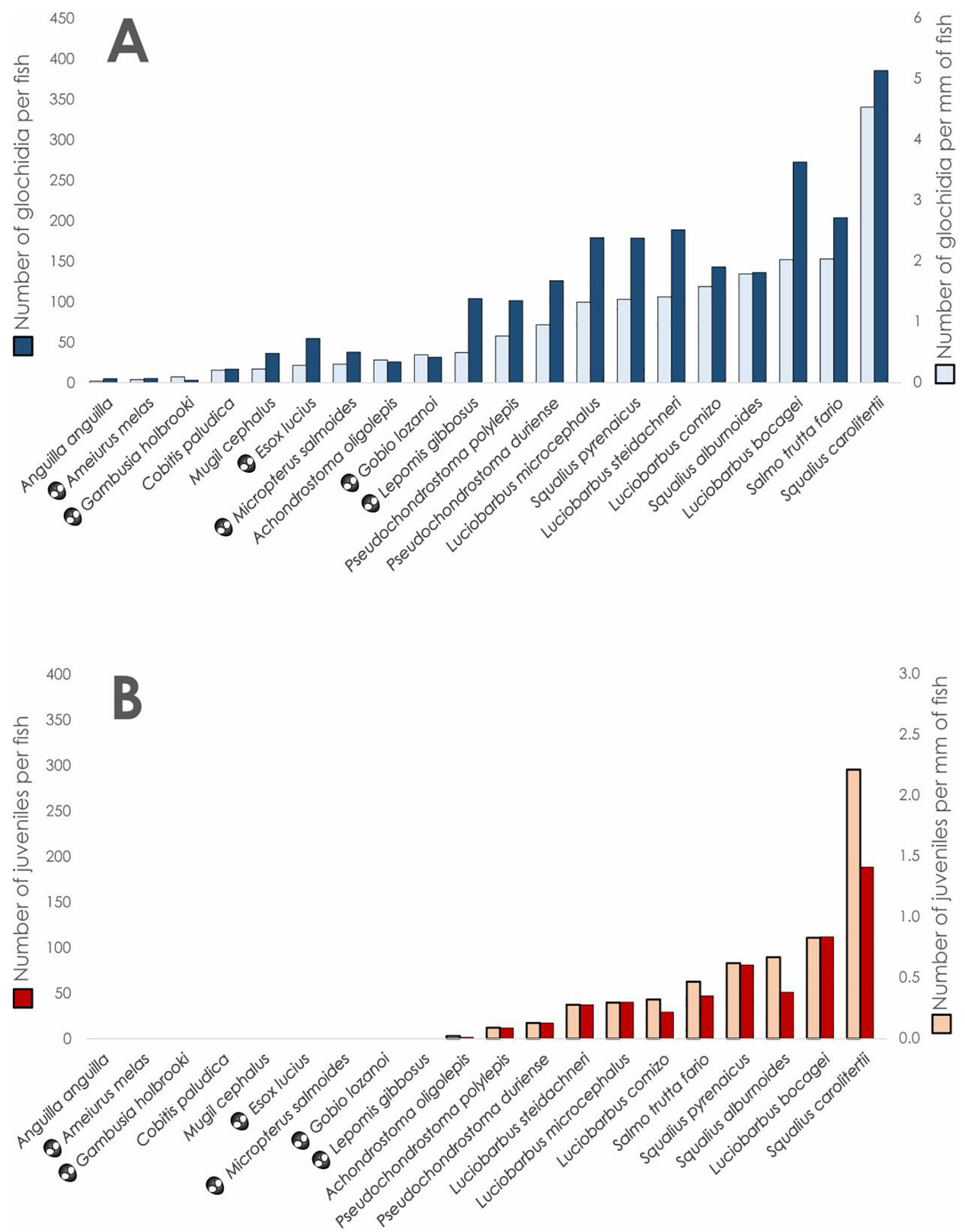

\section{(2) non-native species}

Fig. 6. A - Mean glochidial infestation (i.e. number of glochidia per fish and $\mathrm{mm}$ of fish) in all fish species; B - Effective transformation of glochidia into juveniles (i.e. number of juveniles produced per fish and $\mathrm{mm}$ of fish) in all fish species.

in mucous threads, although feather-like constructs full of glochidia and eggs, also known as conglutinates, are also produced (Fig. 5d). However, as also seen in the congeneric $U$. pictorum, these conglutinates contain variable quantities of mature glochidia and its function is still uncertain, being probably only released by females while under hypoxic stress, to increase ventilation (Aldridge, 1999).

\subsection{Fish hosts}

As in all freshwater mussels, the life cycle of the Iberian dolphin freshwater mussel includes a parasitic stage, in which the larvae (glochidia) need to attach to fish to continue their development and metamorphose into a young juvenile (Modesto et al., 2018). Therefore, it is crucial to understand the dynamic interactions between freshwater mussels and their fish hosts. Our study shows that $U$. delphinus glochidia 


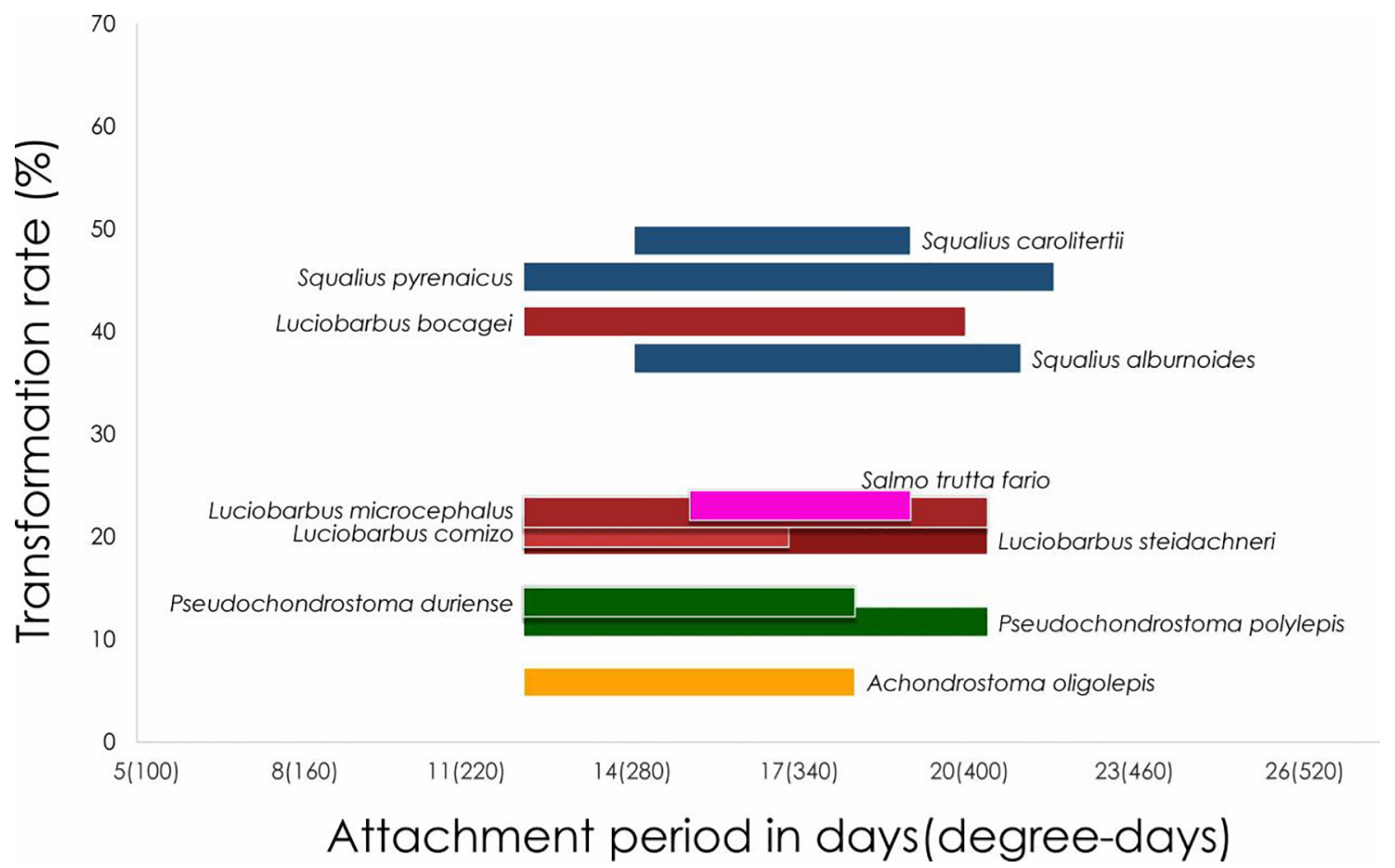

Fig. 7. Glochidial transformation rate and attachment periods (bars) per fish host species.

may attach to all fish species on the trials (Fig. 6; Table 4). However, it attached preferentially to native fish species, with the attachment rates to non-native species being much lower. Furthermore, the effective transformation rate of glochidia into juveniles only occurred in $10 \mathrm{cy}-$ prinid and 1 salmonid native fish species. Transformation rates were especially high in all fish species from the genus Squalius, followed by Luciobarbus, Salmo and Pseudochondrostoma species. This indicates a strong co-evolutionary relationship of $U$. delphinus with native co-occurring fish and especially with Squalius species. This link of the freshwater mussel genus Unio with cyprinids and especially Squalius species has been previously reported (Lopes-Lima et al., 2017a). For example, except for the more divergent Unio tumidus, all European Unio species seem to use at least one species of Squalius as hosts (Lopes-Lima et al., 2017a). Furthermore, Squalius cephalus seems to be the main host in some $U$. crassus populations (Taeubert et al., 2012) and the Southern Iberian $U$. tumidiformis is only able to metamorphose in Squalius species (Reis et al., 2014). The attachment period did not seem to vary much across the effective host species, occurring between 12 and 22 days post attachment at a constant temperature of $20{ }^{\circ} \mathrm{C}$ with the sum of daily temperatures during metamorphosis ranging from 240 to 440 degreedays (Fig. 7; Table 4). This speed of transformation seems to be lower than the southern Iberian U. tumidiformis (Reis et al., 2014) and more like that reported to the more closely related species the Eastern Iberian Unio mancus (Araujo et al., 2005).

\subsection{Practical implications for conservation and environmental monitoring}

Our results have important implications on future management and conservation actions for the Iberian dolphin freshwater mussel $U$. delphinus. The detailed compilation of distribution data and estimation of the EOO and AOO will allow for a more accurate assessment using IUCN categories and criteria (Appendix 2). Information about growth, age of maturity and life span are also especially critical in evaluating the risk of extinction of rare and threatened species, being important components of the evaluation criteria of IUCN Red-Listing. Unionid mussels were for long portrayed as long-lived and slow-growing organisms, but this has been increasingly demystified with species like $U$. delphinus, presenting distinct growth patterns and lifespan (Haag and
Rypel, 2011).

The information about the reproductive cycle here described is very important for future propagation programs and other conservation actions. For instance, gravid females should be searched mainly from late Spring to late Summer. Additionally, if the aim is getting a broodstock of cultivated mussels, only after two years would these mussels be ready for reproduction.

Although $U$. delphinus seems to have a continuous reproductive cycle, both oogenesis and spermatogenesis deaccelerate between August and March. Therefore, translocation and monitoring programs on this species ideally should be done in September before the rainy season to minimize the impact on reproduction, and never during spring/summer where manipulation and transportation stress may lead to reduced reproductive intensity and ejection or abortion of larval content. Potential translocations should take into account that enough time should be given to specimens to settle before the heavy torrential floods that generally occur from October onward, especially in the intermittent rivers in the South.

Knowledge about the fish hosts is also crucial for the future of the species. As already reported in other Mediterranean species (e.g. Unio foucauldianus; Benaissa et al., 2019), especially those with restricted ranges in southern Europe or North Africa, U. delphinus seems to be unable to transform in any of the non-native species. This turns the ongoing biotic homogenization of the Iberian fish fauna due to the constant introduction of new non-native fish species in Iberian freshwater habitats (Clavero et al., 2011, 2013; Anastácio et al., 2019), one of the major threats to this mussel species. Furthermore, species like Lepomis gibbosus and Micropterus salmoides are now major components of many Iberian freshwaters. These fish are piscivorous and very aggressive, making nests at the banks, where $U$. delphinus generally aggregates (Authors pers. obs). These invasive species maintain other native fish species far from the banks, potentially decreasing attachment success of $U$. delphinus larvae. Conversely, most larvae will attach to the non-native fish that will act as ecological sinks. The laboratory host fish studies here developed should be complemented with future field experiments to test which fish species are serving as the effective hosts and to better estimate the impact of invasive species.

Unio delphinus possesses many of the requirements for indicator 
species (Carignan and Villard, 2002), and here we provide a solid and comprehensive ecological and developmental data baseline that will allow developing its potential even further. Besides its inherent conservation importance, information on the growth patterns and lifehistory traits here described should now be optimized for use as ecological indicators. This could be achieved, for instance, by comparing populations exposed to distinct disturbance types and levels. More comprehensive surveys of $U$. delphinus populations and varying compositions of co-occurring fish species could help to develop standardized metrics to assess the status and integrity of fish communities. Given that this mussel is unable to reproduce in most invasive fish, its decline or local extirpation can be a direct effect of the decline, extirpation or changes in the fish fauna. This already occurred in in Lake Banyoles (Spain), where despite good abiotic conditions, all native fish are now extirpated and replaced by many other non-native species, with freshwater mussel populations declining and disappearing soon after (Garcia-Berthou et al., 2000; Araujo et al., 2015).

\section{Conclusions}

Although the study of life-history traits has now become old-fashioned, and generally considered of local/regional interest or purely descriptive, conservation efforts are strongly hindered by the lack of this basic knowledge. Furthermore, many recent studies, e.g., state of the art modelling exercises and multispecies biological and biogeographical meta-analyses, that are attracting a lot of scientific attention, strongly rely on these basic biological data. The present study makes practical considerations about the conservation of a declining freshwater species endemic to one of the global biodiversity hotspots and highlights the need to go back to the basics and to promote the study of life-history traits of poorly studied taxa, especially those of conservation concern.

\section{Declaration of Competing Interest}

The authors declare that they have no known competing financial interests or personal relationships that could have appeared to influence the work reported in this paper.

\section{Acknowledgements}

This work was supported by Portuguese FCT - Foundation for Science and Technology, Projects FRESHCO: Multiple implications of invasive species on Freshwater Mussel co-extinction processes (PTDC/ AGR-FOR/1627/2014-04/SAICT/2015), MUSSELFLOW: Host-dependent evolution, ecology and conservation of freshwater mussels under varying hydrological conditions: consequences of climate change (PTDC/BIA-EVL/29199/2017), and ConBiomics: The missing approach for the Conservation of freshwater Bivalves Project $N^{\circ}$ NORTE-01-0145FEDER-030286, co-financed by COMPETE 2020, Portugal 2020 and the European Union through the ERDF. FCT also supported MLL under grant (SFRH/BD/115728/2016), CM under grant (SFRH/BD/111133/ 2015) and also through Strategic Funding UID/Multi/04423/2019. PB was supported by EDP Biodiversity Chair.

\section{Appendix A. Supplementary data}

Supplementary data to this article can be found online at https:// doi.org/10.1016/j.ecolind.2019.105987.

\section{References}

Aldridge, D.C., 1999. The morphology, growth and reproduction of unionidae (Bivalvia) in a Fenland waterway. J. Molluscan Stud. 65, 47-60. https://doi.org/10.1093/ mollus/65.1.47.

Anastácio, P.M., Ribeiro, F., Capinha, C., Banha, F., Gama, M., Filipe, A.F., Rebelo, R.,
Sousa, R., 2019. Non-native freshwater fauna in Portugal: a review. Sci. Total Environ. 650, 1923-1934. https://doi.org/10.1016/j.scitotenv.2018.09.251.

Araujo, R., 2011. Unio delphinus. The IUCN Red List of Threatened Species 2011: e. T195510A8975648. doi: 10.2305/IUCN.UK.2011-2.RLTS.T195510A8975648.en.

Araujo, R., Gómez, I., Machordom, A., 2005. The identity and biology of Unio mancus Lamarck, 1819 (=U. elongatulus) (bivalvia: unionidae) in the Iberian Peninsula. J. Molluscan Stud. 71, 25-31. https://doi.org/10.1093/mollus/eyi002.

Araujo, R., Reis, J., Machordom, A., Toledo, C., Madeira, M.J., Gómez, I., Velasco, J.C., Barea, J.M., Ondina, P., 2009. Las náyades de la península Ibérica. Iberus 27, 7-72.

Araujo, R., Feo, C., Pou, Q., Campos, M., 2015. Conservation of two endangered European freshwater mussels (Bivalvia: Unionidae): a three-year, semi-natural breeding experiment. Nautilus 129, 126-135.

Araujo, R., Buckley, D., Nagel, K.-O., García-Jiménez, R., Machordom, A., 2018. Species boundaries, geographic distribution and evolutionary history of the Western Palaearctic freshwater mussels Unio (Bivalvia: Unionidae). Zool. J. Linn. Soc. 182, 275-299. https://doi.org/10.1093/zoolinnean/zlx039.

Bauer, G., 1992. Variation in the life span and size of the freshwater pearl mussel. J. Anim. Ecol. 61, 425. https://doi.org/10.2307/5333.

Benaissa, H., Teixeira, A.M., Lopes-Lima, Sousa, R., Varandas, S., Rassam, H., Ghamizi, M., 2019. Fish hosts of the freshwater mussel Unio foucauldianus Pallary, 1936. Aquat. Conserv. Mar. Freshw. Ecosyst. https://doi.org/10.1002/aqc.3234.

Bódis, E., Tóth, B., Sousa, R., 2014. Impact of Dreissena fouling on the physiological condition of native and invasive bivalves: interspecific and temporal variations. Biol. Inv. 16, 1373-1386. https://doi.org/10.1007/s10530-013-0575-z.

Carignan, V., Villard, M.-A., 2002. Selecting indicator species to monitor ecological integrity: a review. Environ. Monit. Assess. 78, 45-61. https://doi.org/10.1023/ A:1016136723584.

Caro, T., 2010. Conservation by Proxy: Indicator, Umbrella, Keystone, Flagship, and Other Surrogate Species. Island Press, New York.

Cek, S., Sereflișan, H., 2006. Certain reproductive characteristics of the freshwater mussel Unio terminalis delicatus (Lea, 1863) in Golbasi Lake, Turkey. Aquac. Res. 37, 1305-1315. https://doi.org/10.1111/j.1365-2109.2006.01563.x.

Cid, N., Bonada, N., Carlson, S., Grantham, T., Gasith, A., Resh, V., Cid, N., Bonada, N., Carlson, S.M., Grantham, T.E., Gasith, A., Resh, V.H., 2017. High variability is a defining component of mediterranean-climate rivers and their Biota. Water 9, 52. https://doi.org/10.3390/w9010052.

Clavero, M., Hermoso, V., 2011. Reservoirs promote the taxonomic homogenization of fish communities within river basins. Biodivers. Conserv. 20, 41-57. https://doi.org/ 10.1007/s10531-010-9945-3.

Clavero, M., Hermoso, V., Aparicio, E., Godinho, F.N., 2013. Biodiversity in heavily modified waterbodies. Freshw. Biol. 58, 1190-1201. https://doi.org/10.1111/fwb. 12120.

Cummings, K.S., Jones, H.A., Lopes-Lima, M., 2016. Rapid bioassessment methods for freshwater molluscs. In: Larsen, T.H. (Ed.), Core Standardized Methods for Rapid Biological Field. Assessment. Conservation International, pp. 185-207.

Douda, K., Lopes-Lima, M., Hinzmann, M., Machado, J., Varandas, S., Teixeira, A., Sousa, R., 2013. Biotic homogenization as a threat to native affiliate species: Fish introductions dilute freshwater mussel's host resources. Divers. Distrib. 19, 933-942. https://doi.org/10.1111/ddi.12044.

Dunca, E., Mutvei, H., 2001. Comparison of microgrowth pattern in Margaritifera mar garitifera shells from south and north Sweden. Am. Malacol. Bull. 16, 239-250.

Ferreira-Rodríguez, N., Akiyama, Y.B., Aksenova, O.V., Araujo, R., Christopher Barnhart, M., Bespalaya, Y.V., Bogan, A.E., Bolotov, I.N., Budha, P.B., Clavijo, C., Clearwater, S.J., Darrigran, G., Do, V.T., Douda, K., Froufe, E., Gumpinger, C., Henrikson, L., Humphrey, C.L., Johnson, N.A., Klishko, O., Klunzinger, M.W., Kovitvadhi, S., Kovitvadhi, U., Lajtner, J., Lopes-Lima, M., Moorkens, E.A., Nagayama, S., Nagel, K.O., Nakano, M., Negishi, J.N., Ondina, P., Oulasvirta, P., Prié, V., Riccardi, N., Rudzìte, M., Sheldon, F., Sousa, R., Strayer, D.L., Takeuchi, M., Taskinen, J., Teixeira, A., Tiemann, J.S., Urbańska, M., Varandas, S., Vinarski, M.V., Wicklow, B.J., Zając, T., Vaughn, C.C., 2019. Research priorities for freshwater mussel conservation assessment. Biol. Conserv. 231, 77-87. https://doi.org/10.1016/J.BIOCON.2019.01. 002 .

Froufe, E., Gonçalves, D.V., Teixeira, A., Sousa, R., Varandas, S., Ghamizi, M., Zieritz, A., Lopes-Lima, M., 2016a. Who lives where? molecular and morphometric analyses clarify which Unio species (Unionida, Mollusca) inhabit the southwestern Palearctic. Org. Divers. Evol. 16, 597-611. https://doi.org/10.1007/s13127-016-0262-x.

Froufe, E., Lopes-Lima, M., Riccard, N., Zaccara, S., Vanetti, I., Lajtner, J., Teixeira, A., Varandas, S., Prie, V., Zieritz, A., Sousa, R., Bogan, A.E., 2017. Lifting the curtain on the freshwater mussel diversity of the Italian Peninsula and Croatian Adriatic coast. Biodivers. Conserv. 26, 3255-3274. https://doi.org/10.1007/s10531-017-1403-z.

Froufe, E., Prié, V., Faria, J., Ghamizi, M., Gonçalves, D.V., Gürlek, M.E., Karaouzas, I., Kebapçi, Ü., Şereflişan, H., Sobral, C., Sousa, R., Teixeira, A., Varandas, S., Zogaris, S., Lopes-Lima, M., 2016b. Phylogeny, phylogeography, and evolution in the Mediterranean region: News from a freshwater mussel (Potomida, Unionida). Mol. Phylogenet. Evol. 100, 322-332. https://doi.org/10.1016/j.ympev.2016.04.030.

Garcia-Berthou, E., Moreno-Amich, R., Coden, A., 2000. Introduction of exotic fish into a Mediterranean lake over a 90-year period. Arch. Hydrobiol. 149, 271-284. https:// doi.org/10.1127/archiv-hydrobiol/149/2000/271.

Geist, J., 2010. Strategies for the conservation of endangered freshwater pearl mussels (Margaritifera margaritifera L.): a synthesis of conservation genetics and ecology. Hydrobiologia 644, 69-88. https://doi.org/10.1007/s10750-010-0190-2.

Gomes-dos-Santos, A., Froufe, E., Gonçalves, D.V., Sousa, R., Prié, V., Ghamizi, M., Benaissa, H., Varandas, S., Teixeira, A., Lopes-Lima, M., 2019. Freshwater conservation assessments in (semi-)arid regions: Testing river intermittence and buffer strategies using freshwater mussels (Bivalvia, Unionida) in Morocco. Biol. Conserv. 236, 420-434. https://doi.org/10.1016/J.BIOCON.2019.05.038. 
Gutierrez, J.L., Jones, C.G., Strayer, D.L., Iribarne, O.O., 2003. Mollusks as ecosystem engineers: the role of shell production in aquatic habitats. Oikos 101, 79-90. https:// doi.org/10.1034/j.1600-0706.2003.12322.x.

Haag, W.R., Rypel, A.L., 2011. Growth and longevity in freshwater mussels: Evolutionary and conservation implications. Biol. Rev. 86, 225-247. https://doi.org/10.1111/j. 1469-185X.2010.00146.x.

Hammer, Ø., Harper, D.A., Ryan, P.D., 2001. PAST: paleontological statistics software package for education and data analysis. Palaeontol. Electron. 4, 9.

Heink, U., Kowarik, I., 2010. What are indicators? on the definition of indicators in ecology and environmental planning. Ecol. Indic. 10, 584-593. https://doi.org/10. 1016/J.ECOLIND.2009.09.009.

Helama, S., Valovirta, I., Nielsen, J.K., 2017. Growth characteristics of the endangered thick-shelled river mussel (Unio crassus) near the northern limit of its natural range. Aquat. Conserv. Mar. Freshw. Ecosyst. 27, 476-491. https://doi.org/10.1002/aqc. 2698.

Hinzmann, M., Lopes-Lima, M., Teixeira, A., Varandas, S., Sousa, R., Lopes, A., Froufe, E., Machado, J., 2013. Reproductive cycle and strategy of Anodonta anatina (L., 1758): notes on hermaphroditism. J. Exp. Zool. Part A Ecol. Genet. Physiol. 319, 378-390. https://doi.org/10.1002/jez.1801.

Hochwald, S., 2001. Plasticity of life-history traits in Unio crassus. In: Bauer, G., Wächtler, K. (Eds.), Ecology and Evolution of the Freshwater Mussels Unionoida. Springer, Berlin, Heidelberg, pp. 127-141.

IUCN Standards and Petitions Committee, 2019. Guidelines for Using the IUCN Red List Categories and Criteria. Version 14. Prepared by the IUCN Standards and Petitions Committee. http://www.iucnredlist.org/documents/RedListGuidelines.pdf (accessed 19 November 2019).

Kat, P.W., 2009. Sexual selection and simultaneous hermaphroditism among the Unionidae (Bivalvia: Mollusca). J. Zool. 201, 395-416. https://doi.org/10.1111/j. 1469-7998.1983.tb04284.x.

Lambeck, R.J., 1997. Focal species: a multi-species umbrella for nature conservation. Conserv. Biol. 11, 849-856. https://doi.org/10.1046/j.1523-1739.1997.96319.x.

Lopes-Lima, M., Teixeira, A., Froufe, E., Lopes, A., Varandas, S., Sousa, R., 2014. Biology and conservation of freshwater bivalves: past, present and future perspectives. Hydrobiologia 735, 1-13. https://doi.org/10.1007/s10750-014-1902-9.

Lopes-Lima, M., Sousa, R., Geist, J., Aldridge, D.C., Araujo, R., Bergengren, J., Bespalaya, Y., Bódis, E., Burlakova, L., Van Damme, D., Douda, K., Froufe, E., Georgiev, D., Gumpinger, C., Karatayev, A., Kebapçi, Ü., Killeen, I., Lajtner, J., Larsen, B.M., Lauceri, R., Legakis, A., Lois, S., Lundberg, S., Moorkens, E., Motte, G., Nagel, K.O., Ondina, P., Outeiro, A., Paunovic, M., Prié, V., von Proschwitz, T., Riccardi, N., Rudzīte, M., Rudzītis, M., Scheder, C., Seddon, M., Şereflişan, H., Simić, V., Sokolova, S., Stoeckl, K., Taskinen, J., Teixeira, A., Thielen, F., Trichkova, T., Varandas, S., Vicentini, H., Zajac, K., Zajac, T., Zogaris, S., 2017a. Conservation status of freshwater mussels in Europe: state of the art and future challenges. Biol. Rev. 92, 572-607. https://doi.org/10.1111/brv.12244.

Lopes-Lima, M., Froufe, E., Do, V.T., Ghamizi, M., Mock, K.E., Kebapçı, Ü., Klishko, O. Kovitvadhi, S., Kovitvadhi, U., Paulo, O.S., Pfeiffer, J.M., Raley, M., Riccardi, N., Şereflişan, H., Sousa, R., Teixeira, A., Varandas, S., Wu, X., Zanatta, D.T., Zieritz, A., Bogan, A.E., 2017b. Phylogeny of the most species-rich freshwater bivalve family (Bivalvia: Unionida: Unionidae): Defining modern subfamilies and tribes. Mol. Phylogenet. Evol. 106, 174-191. https://doi.org/10.1016/j.ympev.2016.08.021.

Lopes-Lima, M., Burlakova, L.E., Karatayev, A.Y., Mehler, K., Seddon, M., Sousa, R., 2018. Conservation of freshwater bivalves at the global scale: diversity, threats and research needs. Hydrobiologia 810, 1-14. https://doi.org/10.1007/s10750-017-3486-7.

Meira, A., Lopes-Lima, M., Varandas, S., Teixeira, A., Arenas, F., Sousa, R., 2019. Invasive crayfishes as a threat to freshwater bivalves: Interspecific differences and conservation implications. Sci. Total Environ. 649, 938-948. https://doi.org/10.1016/J. SCITOTENV.2018.08.341.

Modesto, V., Ilarri, M., Souza, A.T., Lopes-Lima, M., Douda, K., Clavero, M., Sousa, R., 2018. Fish and mussels: importance of fish for freshwater mussel conservation. Fish Fish. 19, 244-259. https://doi.org/10.1111/faf.12252.

Modesto, V., Castro, P., Lopes-Lima, M., Antunes, C., Ilarri, M., Sousa, R., 2019. Potential impacts of the invasive species Corbicula fluminea on the survival of glochidia. Sci. Total Environ. 673, 157-164. https://doi.org/10.1016/j.scitotenv.2019.04.043.

Myers, N., Mittermeier, R.A., Mittermeier, C.G., da Fonseca, G.A., Kent, J., 2000. Biodiversity hotspots for conservation priorities. Nature 403, 853-858. https://doi. org $/ 10.1038 / 35002501$.

Noss, R.F., O'Connell, M.A., Murphy, D.D., 1997. The Science of Conservation Planning: Habitat Conservation under the Endangered Species Act. Island Press, Washington.

Oliveira, J.M., Santos, J.M., Teixeira, A., Ferreira, M.T., Pinheiro, P.J., Geraldes, A. Bochechas, E.J., 2007. Projecto Aquariport: Programa nacional de Monitorização de Recursos Piscícolas e de Avaliação da Qualidade Ecológica de rios. Direcção-Geral
Dos Recursos Florestais, Lisboa, Portugal.

Ostrovsky, I., Gophen, M., Kalikhman, I., 1993. Distribution, growth, production, and ecological significance of the clam Unio terminalis in Lake Kinneret, Israel. Hydrobiologia 271, 49-63. https://doi.org/10.1007/BF00005695.

Reis, J., 2006. Atlas dos Bivalves de Água Doce em Portugal Continental. Instituto da Conservação da Natureza, Lisboa, Portugal.

Reis, J., Collares-Pereira, M.J., Araujo, R., 2014. Host specificity and metamorphosis of the glochidium of the freshwater mussel Unio tumidiformis (Bivalvia: Unionidae). Folia Parasitol. (Praha) 61, 81-89. https://doi.org/10.14411/fp.2014.005.

Reis, J., Araujo, R., 2016. Life history of the freshwater mussel Unio tumidiformis (Bivalvia: Unionidae) in a temporary Mediterranean-type stream. Invertebr. Biol. 135, 31-45. https://doi.org/10.1111/ivb.12114.

Rizhinashvili, A.L., 2008. On the relationships between absolute and allometric shell growth in unionid mussels (Bivalvia, Unionidae) from European Russia. Inl. Water Biol. 1, 241-247. https://doi.org/10.1134/S1995082908030073.

Robson, B.J., Chester, E.T., Mitchell, B.D., Matthews, T.G., 2013. Disturbance and the role of refuges in Mediterranean climate streams. Hydrobiologia 719, 77-91. https://doi. org/10.1007/s10750-012-1371-y.

San Miguel, E., Monserrat, S., Fernández, C., Amaro, R., Hermida, M., Ondina, P., Altaba C.R., 2004. Growth models and longevity of freshwater pearl mussels (Margaritifera margaritifera) in Spain. Can. J. Zool. 82, 1370-1379. https://doi.org/10.1139/z04113.

Schöne, B., Dunca, E., Mutvei, H., Norlund, U., Schone, B., 2004. A 217-year record of summer air temperature reconstructed from freshwater pearl mussels (M. margarifitera, Sweden). Quat. Sci. Rev. 23, 1803-1816. https://doi.org/10.1016/j.quascirev. 2004.02.017.

SNIRH, 2019. Sistema Nacional de Informação de Recursos Hídricos. https://snirh. apambiente.pt/ (accessed 19 November 2019).

Sousa, R., Pilotto, F., Aldridge, D.C., 2011. Fouling of European freshwater bivalves (Unionidae) by the invasive zebra mussel (Dreissena polymorpha). Freshw. Biol. 56, 867-876. https://doi.org/10.1111/j.1365-2427.2010.02532.x.

Sousa, R., Varandas, S., Cortes, R., Teixeira, A., Lopes-Lima, M., Machado, J., Guilhermino, L., 2012. Massive die-offs of freshwater bivalves as resource pulses. Ann. Limnol. - Int. J. Limnol. 48, 105-112. https://doi.org/10.1051/limn/2012003.

Sousa, R., Novais, A., Costa, R., Strayer, D.L., 2014. Invasive bivalves in fresh waters: impacts from individuals to ecosystems and possible control strategies. Hydrobiologia 735, 233-251. https://doi.org/10.1007/s10750-012-1409-1.

Sousa, R., Ferreira, A., Carvalho, F., Lopes-Lima, M., Varandas, S., Teixeira, A., 2018. Dieoffs of the endangered pearl mussel Margaritifera margaritifera during an extreme drought. Aquat. Conserv. Mar. Freshw. Ecosyst. 28, 1244-1248. https://doi.org/10. 1002/aqc. 2945.

Sousa, R., Nogueira, J.G., Ferreira, A., Carvalho, F., Lopes-Lima, M., Varandas, S., Teixeira, A., 2019. A tale of shells and claws: the signal crayfish as a threat to the pearl mussel Margaritifera margaritifera in Europe. Sci. Total Environ. 665, 329-337. https://doi.org/10.1016/J.SCITOTENV.2019.02.094.

Strayer, D.L., 2017. What are freshwater mussels worth? Fresh. Mol. Biol. Conserv. 20, 103-114. https://doi.org/10.31931/fmbc.v20i2.2017.103-113.

Strayer, D.L., Downing, J.A., Haag, W.R., King, T.L., Layzer, J.B., Newton, T.J., Nichols, S.J., 2004. Changing perspectives on pearly mussels, North America's most imperiled animals. Bioscience 54, 429-439. https://doi.org/10.1641/0006-3568(2004) 054[0429:CPOPMN]2.0.CO;2.

Taeubert, J.-E., Gum, B., Geist, J., 2012. Host-specificity of the endangered thick-shelled river mussel (Unio crassus, Philipsson 1788) and implications for conservation. Aquat. Conserv. Mar. Freshw. Ecosyst. 22, 36-46. https://doi.org/10.1002/aqc.1245.

Van der Schalie, H., 1970. Hermaphroditism among North American freshwater mussels. Malacologia 10, 93-112.

Van Hassel, J.H., Farris, J.L., 2007. A review of the use of unionid mussels as biological indicators of ecosystem health. In: Van Hassel, J.H., Farris, J.L. (Eds.), Freshwater Bivalve Ecotoxicology. CRC Press, pp. 19-49.

Varandas, S., Assunção, T., Almeida, P., Cortes, R., Crespí, A., Ferreira, P., Froufe, E., Hinzmann, M., Jesus, J., Lopes-Lima, M., Lopes, M., Magalhães, M., Pereira, V., Santos, C., Sousa, R., Teixeira, A., 2014. PAELORIS: Guia de Flora e Fauna aquáticas das Lagoas Costeiras do Sítio Rede Natura 2000: Dunas de Mira, Gândara e Gafanhas. I.P.B., U.T.A.D., U.M., CIIMAR, C.M.F.F. e C.M.M., Bragança, Portugal.

Vaughn, C.C., 2018. Ecosystem services provided by freshwater mussels. Hydrobiologia 810, 15-27. https://doi.org/10.1007/s10750-017-3139-x.

Walford, L.A., 1946. A new graphic method of describing the growth of animals. Biol. Bull. 90, 141-147. https://doi.org/10.2307/1538217.

Ziuganov, V., Zotin, A., Nezlin, L., Tretiakov, V., 1994. The Freshwater Pearl Mussels and their Relationships with Salmonid Fish. VNIRO, Moscow. 